Published in "Sedimentary Geology 317: 87-101, 2015"

which should be cited to refer to this work.

\title{
Contribution to the understanding of the Ionian Basin sedimentary evolution along the eastern edge of Apulia during the Late Cretaceous in Albania
}

\author{
J. Le Goff ${ }^{\mathrm{a}, \mathrm{b}}$, A. Cerepi ${ }^{\text {a }}$, R. Swennen ${ }^{\mathrm{b}}$, C. Loisy $^{\mathrm{a}}$, M. Caron ${ }^{\mathrm{c}}$, K. Muska ${ }^{\mathrm{d}}$, H. El Desouky ${ }^{\mathrm{b}, \mathrm{e}}$ \\ a EA 4592 GEE, University of Bordeaux, ENSEGID-IPB, 1 allée Fernand Daguin, 33607 Pessac Cedex, France \\ ${ }^{\mathrm{b}}$ KU Leuven, Celestijnenlaan 200 E, B 3001 Heverlee, Belgium \\ c Fribourg University, Impasse de la Butte, 7, CH-1700 Fribourg, Switzerland \\ d Polytechnic University of Tirana, Albania \\ e Geology Department, Menoufia University, 32512 Shebin El-Kom, Menoufia, Egypt
}

\begin{abstract}
Integrated in the peri-Adriatic domain, the Ionian Basin extended along a NW-SE direction during the Late Cretaceous, limited on its sides by the Apulian and the Kruja platforms. The basinal/slope succession was studied in seven outcrops exposed in the Albanian fold-and-thrust belt. Sedimentological investigations, supported by bio- and chronostratigraphy were performed on calcareous Upper Cretaceous hemipelagites, gravity-flow deposits and slumps. The western part of the basin was studied, revealing a strong influence of the Apulian margin, alternatively shedding sediment basinward, by means of a tectonically controlled edge. The Late Albian to Cenomanian period is characterized by the settling of muddy debrites along the margin. A deep basinal environment characterizes this period which prolongs until the Santonian, with no significant influx of the platform basinward. This sedimentary setting abruptly changed at the end of the Santonian, with an important influx derived from both platforms. Coarsening and thickening upward sequences show a progressive increase in sediment shedding during the Campanian. The Late Campanian-Early Maastrichtian period points out a major change on the resedimentation processes with the settling of several slumped units reworking thick sediment packages. The latter can be traced along the Apulian margin, testifying of instabilities along the edge of Apulia.
\end{abstract}

\section{Introduction}

Characteristic features of carbonate platform margins have for a long time instigated scientific investigations (Cook et al., 1972; Read, 1982). Modern and ancient systems investigated throughout the world revealed significant differences when compared with their siliciclastic counterparts in terms of facies, morphology and dynamics. Among the characteristics of carbonate systems, common features are i) the "sheetlike" character of resedimented deposits (Crevello and Schlager, 1980; Schlager and Ginsburg, 1981; Mullins and Cook, 1986; Drzewiecki and Simó, 2002; Etienne, 2012), ii) the "line-source", or apron-like morphology of many carbonate slopes (Mullins and Cook, 1986; Playton et al., 2010), and iii) the "highstand shedding" of carbonate platforms basinward (Droxler and Schlager, 1985; Eberli, 1991; Schlager et al., 1994; Bernet et al., 2000). The Late Cretaceous paleogeography of the Neo-Tethys, dominated by a framework of carbonate platforms and basins (Channell et al.,

E-mail addresses: johan.le goff@ensegid.fr (J. Le Goff), Rudy.Swennen@ees.kuleuven.be (R. Swennen), michele.caron@bluewin.ch (M. Caron), kristaqmuska@yahoo.fr (K. Muska), Geohamdy@yahoo.com (H. El Desouky).
1979; D' Argenio et al., 1980; Zapaterra, 1994), is adequate for the study of carbonate margin evolution. During this period, the Apulian and Gavrovo-Tripolitza (Kruja) platforms developed in the peri-Adriatic region, separated by the Ionian Basin. The latter exposes resedimented deposits that have been extensively studied by a number of authors in a small area, i.e. the Gargano promontory, exposing an example of a platform-to-basin relation (Borgomano, 1987, 2000; Bosellini et al., 1993, 1999; Graziano, 2000, 2001; Hairabian et al., 2014-in this volume). In contrast, little information exists with regard to the sedimentary processes involved in the sedimentation of a thick succession of about $300 \mathrm{~m}$ of Upper Cretaceous deposits outcropping in Albania. Dewever et al. (2007), Vilasi (2009) and Rubert et al. (2012) recently gave a first overview of the resedimented facies composing the basinal succession. Nevertheless, little assessment was provided regarding the sediment distribution along the Apulian carbonate margin and the basinal characteristics.

The aim of this paper is to understand the sedimentary dynamics of the Ionian Basin during the Late Cretaceous. Special attention is given to the identification of specific sedimentation stages related to the interplay between eustacy, tectonics and sediment supply governing the evolution of this carbonate system. The studied successions give new 
insights for the geometrical characterization of sediment accumulations along the Apulian edge at a reservoir scale. This architectural framework is potentially of high interest, considering that the Upper Cretaceous to Paleocene interval is recognized as the main oil bearing reservoir unit in Albania.

\section{Geological setting}

The Albanides (Channell et al., 1979; Meço et al., 2000; Robertson and Shallo, 2000) are composed of seven litho-tectonic units or zones (Fig. 1) integrated in the Albanian fold-and-thrust belt (Swennen et al., 2003; Vilasi, 2009) which extends along the country following a NNE-SSW orientation (Fig. 1). This structural framework is inherited from several phases of deformation that affected the deposits during the Alpine Orogeny from Late Eocene to Pliocene, following a westward propagation of the thrust front (Aubouin, 1959; Meço et al., 2000; Robertson and Shallo, 2000). In the south of Albania, the external
Albanides are broadly exposed, revealing from east to west, the Kruja, Ionian and Sazani zones (Fig. 1B, C). These zones are respectively related to the Kruja Platform, the Ionian Basin and the Apulian Platform (Fig. 1A, B) which developed during the Mezosoic in the peri-Adriatic region (Channell et al., 1979; Robertson and Shallo, 2000).

A syn-rifting regime is attested from the Middle Jurassic till the Early Cretaceous (Channell et al., 1979; Zapaterra, 1994; Borgomano, 2000; Karakitsios, 2013). It is characterized by the progressive settling of a monotonous basinal sedimentation within the Ionian Basin, while platform sedimentation took place on the adjacent Apulia and Kruja Platforms (Brahimi et al., 1992; Zapaterra, 1994; Meço et al., 2000). A post-rifting regime is assumed from Early Cretaceous (Karakitsios, 2013) with an enhanced differentiation of the platform/basin system and a progressive influx of calciclastic material into the Ionian Basin provided from the Apulian and Kruja Platforms (Skourtsis-Coroneou et al., 1995; Karakitsios, 2013). In Greece, autochthonous basinal sedimentation is attested in the Vigla Formation (Aptian-Early Turonian) while

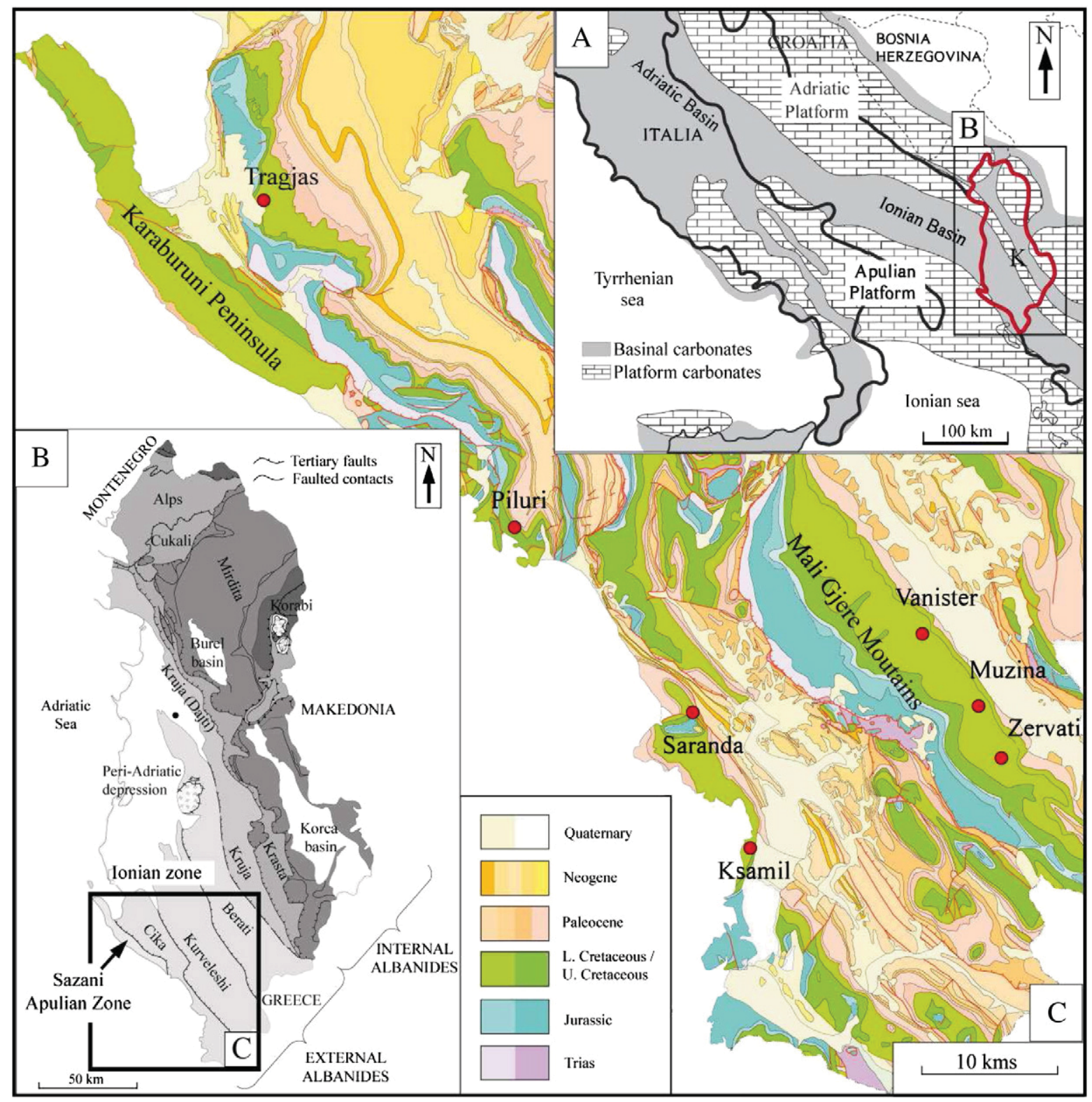

Fig. 1. (A) Middle-Late Liassic to Late Cretaceous facies map of the peri-Adriatic region, modified from Rubert et al. (2012) and Zapaterra (1994). Abbreviations: K, Kruja Platform. (B) Simplified litho-tectonic map of Albania, with indication of the study area (rectangle), modified from Moisiu and Gurabardhi (2004) and Rubert et al. (2012). (C) Location of the studied outcrops, projected on the geological map modified from Moisiu and Gurabardhi (2004). 
calciturbidites of mixed pelagic and benthic fauna (Skourtsis-Coroneou et al., 1995; Karakitsios, 2013) compose the Senonian limestones. In Italy, the Ionian Basin deposits of the Gargano promontory expose megabreccias attesting syn-sedimentary tectonics affecting the Apulian platform during Aptian-Albian (Bosellini et al., 1993, 1999; Borgomano, 2000; Graziano, 2000; Hairabian et al., 2014-in this volume). During the Late Cretaceous, base-of-slope deposits composed of carbonate breccias and bioclastic grainstones are reported during the Cenomanian and Coniacian-Maastrichtian (Monte San Angelo, Nevarra, Caramanica Formations) while the Turonian corresponds to a sedimentary hiatus in the basin, related to an emersion phase of the platform (Borgomano, 1987, 2000). To the east, the influence of the Kruja Platform in the basinal resedimentation is less understood (Fig. 1A). However, periods of instabilities are recognized from the Santonian, responsible for a breakup of the platform in two distinctive parts (Heba and Prichonnet, 2009). The Early Maastrichtian to the Paleocene is marked by a discontinuity, which point out an emersion of the platform during this period (Landrein et al., 2001; Heba and Prichonnet, 2006, 2009).

\section{Material and methods}

\subsection{Field investigation}

Investigations were performed on seven outcrops situated within two of the three thrust belts in the Ionian Basin (Fig. 1B, C). To the west, the Cika belt was investigated in four different outcrops. From the NW to the SE, these are the Tragjas, Piluri, Saranda and Ksamil outcrops. To the east, the Kurveleshi belt was investigated in three outcrops across the Mali Gjere. From the NW to the SE they respectively correspond to the Vanister, Muzina and Zervati outcrops (Fig. 1C). Three outcrops (Vanister, Muzina and Piluri) studied by Rubert et al. (2012) were re-investigated. Basinal successions were studied in detail on a 1/50 scale. Granulometry, texture, biological compounds and sedimentary structures are recorded together with the description of gravity-flow deposits. Representative samples were taken for petrographic characterization. Considering the multi-layer syn-sedimentary deformation intervals within the basinal succession (Rubert et al., 2012), a morphological characterization was performed based on a dual scale approach. Firstly, panoramic pictures gathered from around 30 large-scale outcrops helped in unraveling the deformation style of deformed intervals. Secondly, detailed deformation features described at the outcrop gave significant information to address the characteristics of the reworked layers and helped in unraveling the associated processes of reworking.

\subsection{Biostratigraphy}

On the basis of thin section petrographical descriptions, the determination of pelagic foraminifera provided significant information to deduce geologic ages of the studied successions. Our results were compared to previous studies focusing especially on the paleontology (Brahimi et al., 1987, 1992) established for the Piluri and Muzina outcrops (Fig. 1B).

\subsection{Strontium isotopes}

The evolution during the Late Cretaceous is favorable for the application of Strontium Isotope Stratigraphy (SIS) since a clear rising trend exists through time, thus avoiding problems of "twin" ages. The $\mathrm{Rb}$ and $\mathrm{Sr}$ contents and the ${ }^{87} \mathrm{Rb} /{ }^{86} \mathrm{Sr}$ and ${ }^{87} \mathrm{Sr} /{ }^{86} \mathrm{Sr}$ ratios were determined for a total of 18 representative carbonate samples from the Upper Cretaceous sections of Saranda, Dhuvjani (situated between Muzina and Vanister) and Vanister (Table 1). One outcrop is related to a proximal setting (Saranda, Cika Belt, Fig. 1B), and two others are related to a distal setting (Vanister and Dhuvjani outcrops, Kurveleshi Belt, Fig. 1B). The Rb-Sr analyses were performed at the Department of Analytical Chemistry, Ghent University (Belgium). The carbonate powders were weighed in screw-capped Savillex® PFA vials and dissolved in $6 \mathrm{M} \mathrm{HCl}$ on a hotplate. The digests were subsequently evaporated to dryness and redissolved in $7 \mathrm{M} \mathrm{HNO}_{3}$. The $\mathrm{Rb}$ and $\mathrm{Sr}$ concentrations were determined using a Thermo Scientific XSeries 2 quadrupole-based ICP-MS instrument using external calibration combined with $\mathrm{Y}$ as internal standard (Vanhaecke et al., 1992). The ${ }^{87} \mathrm{Rb} /{ }^{86} \mathrm{Sr}$ ratios were calculated from the ICP-MS elemental concentrations taking into account the $\mathrm{Sr}$ isotopic composition of the samples, following the procedures described by Vanhaecke et al. (1999). Sr was isolated from the sample matrix using a Sr spec ${ }^{\mathrm{TM}}$ resin, following the isolation procedure of De Muynck et al. (2009). Sr isotopic measurements were performed using a Thermo Scientific Neptune MC-ICP-MS instrument. The intensities obtained for ${ }^{83} \mathrm{Kr}$ and ${ }^{85} \mathrm{Rb}$ were used to correct for the $\mathrm{Kr}$ and $\mathrm{Rb}$ interferences (Balcaen et al., 2005). The Sr isotopic ratios were normalized to the accepted ${ }^{86} \mathrm{Sr} /{ }^{88} \mathrm{Sr}$ ratio of 0.1194 (Steiger and Jager, 1977). Blank Sr signals were negligible compared to the $\mathrm{Sr}$ intensities encountered for samples and standards. Repeated analyses of the NIST SRM $987 \mathrm{SrCO}_{3}$ over the duration of this study yielded an average ${ }^{87} \mathrm{Sr} /{ }^{86} \mathrm{Sr}$ ratio with a corresponding $2 \sigma$ uncertainty interval of $0.710299 \pm 0.000022(\mathrm{n}=33)$, well in agreement with the accepted ${ }^{87} \mathrm{Sr} /{ }^{86} \mathrm{Sr}$ ratio of 0.710248 for this material (Thirlwall, 1991). The ${ }^{87} \mathrm{Sr} /{ }^{86} \mathrm{Sr}$ ratios of the samples were normalized to the value of 0.710248 for NIST 987.

\section{Bio and chronostratigraphic results}

\subsection{Biostratigraphic analysis}

Four main biostratigraphic zonations can be individualized within the studied successions, namely: i) the Lower Albian to Cenomanian interval, which constitutes the basal part of the studied successions. It is characterized by an association of Ticinella sp., Biticinella sp. (breggiensis) and Rotalipora sp. (ticinensis) (Fig. 2). They are regularly associated with abundant radiolaria. ii) the Turonian to Lower Senonian (Coniacian and Santonian) interval is defined with the occurrence of Helvetoglobotruncana sp. (helvetica), Dicarinella sp. (primitiva, imbricata), Praeglobotruncana sp. (turbinata), and Marginotruncana sp (Fig. 2). Those species were poorly recognized in thin sections. iii) the CampanianMaastrichtian possesses a rich fauna association. Globotruncanita sp. (stuartiformis, stuarti, angulata, conica), Globotruncana sp. (lapparenti, linneiana, arca, bulloides, ventricosa), and Rugoglobigerina sp. were identified within the deposits (Fig. 2). iv) the Paleocene interval is marked by the presence of Morozovella sp., Subbotina sp., Woodringina sp., Globigerina sp., Gumbelitria sp. and Igorina sp. (Fig. 2).

\subsection{Chronostratigraphic analysis}

The Sr-isotope results of the 18 analyzed samples are given in Table 1, and numerical ages are inserted alongside their respective stratigraphic position in Fig. 2. Values range from 0.707447 to 0.707860 . All samples display very low ${ }^{87} \mathrm{Rb} /{ }^{86} \mathrm{Sr}$ ratios (mean $=0.0038$, Table 1 ), thus no correction for the Rb decay needed to be carried out. The numerical age of each carbonate sample was obtained by comparing its ${ }^{87} \mathrm{Sr} /{ }^{86} \mathrm{Sr}$ ratio with the Late Cretaceous global seawater curve of the LOWESS look-up table version 4:08/04 (McArthur et al., 2001). The lowest ${ }^{87} \mathrm{Sr} /{ }^{86} \mathrm{Sr}$ ratio suggests a Santonian age (85.22 Ma, Table 1, Fig. 2) while the highest values (samples 5, 9 and 18) are undefined by the LOWESS look-up table. The trend of ${ }^{87} \mathrm{Sr} /{ }^{86} \mathrm{Sr}$ ratio shows an increasing trend during the Late Cretaceous, and evidences a decreasing trend from the K/P limit and during the Paleocene. During the Latest Cretaceous, $\mathrm{Sr}$ isotope ratios of the Cretaceous marine seawater reached to their maximum before they decline again at the beginning of the Paleocene (McArthur et al., 1998). At this transition period, the marine seawater possessed abnormal Sr isotope values (McArthur et al., 1998), which are excluded in the statistical best fit of the LOWESS look-up table. Consequently, it is assumed that samples 5, 9 and 18 belong to the youngest part of the Late Cretaceous ( 65.5 Ma) near the $\mathrm{K} / \mathrm{P}$ 
Table 1

${ }^{87} \mathrm{Rb} /{ }^{86} \mathrm{Sr}$ and ${ }^{87} \mathrm{Sr} /{ }^{86} \mathrm{Sr}$ ratios and the corresponding numerical ages of the 18 carbonate samples from the Upper Cretaceous sections of Saranda, Vanister and Dhuvjani (with standard deviation for ${ }^{87} \mathrm{Rb} /{ }^{86} \mathrm{Sr}<0,0002 ; 2 \mathrm{SD}$ of ${ }^{87} \mathrm{Sr} /{ }^{86} \mathrm{Sr}<0,00007$ ). The ages are derived from the LOWESS look-up table (version 4:08/04; Howarth et al., 1997; McArthur et al., 2001). Abbreviation: K/P; Cretaceous/Paleocene limit

\begin{tabular}{|c|c|c|c|c|c|c|c|c|}
\hline Sample number & Outcrop & Stratigraphic position (m) & ${ }^{87} \mathrm{Rb} /{ }^{86} \mathrm{Sr}$ & $2 \sigma$ & ${ }^{87} \mathrm{Sr} /{ }^{86} \mathrm{Sr}$ & $2 \sigma$ & Age & \\
\hline 1 & Saranda & 48 & 0.010159 & 0.000172 & 0.707447 & 0.000034 & 85.22 & SANTONIAN \\
\hline 2 & Saranda & 96 & 0.011217 & 0.000080 & 0.707481 & 0.000037 & 83.12 & CAMPANIAN \\
\hline 3 & Saranda & 113 & 0.006505 & 0.000112 & 0.707703 & 0.000062 & 71.94 & CAMPANIAN \\
\hline 4 & Saranda & 177 & 0.000558 & 0.000022 & 0.707774 & 0.000040 & 69.12 & MAASTRICHTIAN \\
\hline 5 & Saranda & 210 & 0.001360 & 0.000041 & 0.707843 & 0.000027 & 65.57 & $\mathrm{~K} / \mathrm{P}$ \\
\hline 6 & Vanister & 15 & 0.006864 & 0.000088 & 0.707720 & 0.000014 & 71.60 & CAMPANIAN \\
\hline 7 & Vanister & 64 & 0.004797 & 0.000032 & 0.707743 & 0.000027 & 70.45 & MAASTRICHTIAN \\
\hline 8 & Vanister & 77 & 0.000718 & 0.000019 & 0.707760 & 0.000006 & 69.71 & MAASTRICHTIAN \\
\hline 9 & Vanister & 139 & 0.004617 & 0.000081 & 0.707838 & 0.000017 & 65.57 & $\mathrm{~K} / \mathrm{P}$ \\
\hline 10 & Vanister & 148 & 0.002958 & 0.000017 & 0.707815 & 0.000001 & 66.97 & MAASTRICHTIAN \\
\hline 11 & Dhuvjani & 44 & 0.003128 & 0.000053 & 0.707487 & 0.000029 & 82.74 & CAMPANIAN \\
\hline 12 & Dhuvjani & 173 & 0.005957 & 0.000093 & 0.707673 & 0.000008 & 72.93 & CAMPANIAN \\
\hline 13 & Dhuvjani & 215 & 0.001063 & 0.000026 & 0.707681 & 0.000052 & 72.65 & CAMPANIAN \\
\hline 14 & Dhuvjani & 243 & 0.002125 & 0.000036 & 0.707741 & 0.000022 & 70.55 & MAASTRICHTIAN \\
\hline 15 & Dhuvjani & 260 & 0.000871 & 0.000010 & 0.707772 & 0.000012 & 69.20 & MAASTRICHTIAN \\
\hline 16 & Dhuvjani & 281 & 0.003398 & 0.000081 & 0.707822 & 0.000016 & 66.66 & MAASTRICHTIAN \\
\hline 17 & Dhuvjani & 289 & 0.002682 & 0.000099 & 0.707780 & 0.000031 & 68.85 & MAASTRICHTIAN \\
\hline 18 & Dhuvjani & 302 & 0.009575 & 0.000134 & 0.707860 & 0.000033 & 65.57 & $\mathrm{~K} / \mathrm{P}$ \\
\hline
\end{tabular}

transition. Minor incompatibilities are evidenced for samples 10 and 16 sampled in calcilutitic sediments with calcarenitic lenses. Sample 10 suggests an older age than sample 9 , whereas sample 16 suggests an older age than sample 17 (Table 1, Fig. 2). The Sr-isotope data obtained from the different studied sections spread from Santonian times till the Cretaceous/Paleocene boundary age.

Bio- and chronostratigraphical results obtained for the Upper Cretaceous carbonate deposits of the studied successions are in line with each other (Fig. 2). The K/P limit pointed out by Rubert et al. (2012) in the Muzina and Vanister outcrops is confirmed by the stratigraphical data, and can be confidently extended over the Mali Gjere Mountains (Fig. 1C). Chronostratigraphical analysis is undoubtedly suitable to precise the timing of deposition during the Campanian-Maastrichtian. Significant thicknesses of deposits are documented in the Ionian Basin during this long time interval ( $18 \mathrm{Ma}$ ) and the definition of pelagic foraminifera associations remains limited to discriminate the two time periods. Moreover, the chronostratigraphic analysis is of considerable interest to accurately precise ages of specific strata. In this regard the first well-bedded gravity-flow deposit covering each slump unit $(1,2$, and 3, Fig. 2) allows accurate constraining of the age of the underlying destabilization. However, the timing of deposition could be improved in the lower part of the Upper Cretaceous succession. The chronostratigraphical analysis, coupled with biostratigraphical control on pelagic foraminifera gives good perspectives in this way.

\section{Sedimentary beds}

Based on the concept that "each turbidite is the result of a single, short-lived event, and once deposited it is extremely unlikely to be reworked by other currents" (Walker, 1984), the following classification embraces the notion of individual elements (Stow and Mayall, 2000). Thus, in this study, descriptions focus on single depositional events represented in vertical sequences that form beds (Kneller and McCaffrey, 2003), which consist of several subdivisions characterized by specific sedimentary structures (Bouma, 1962; Lowe, 1976, 1982; Stow and
Shanmugan, 1980; Kneller and McCaffrey, 2003). A brief description follows below, whereby sedimentary structures are depicted for each bed. Some field illustrations are presented in Fig. 3. An interpretation in terms of dominant grain support mechanism following the classification of Mulder and Alexander (2001) is given for each bed, and represented in Fig. 4. Based on the comparison with another carbonate slope system presenting similar deposits (the Bahamas, Mullins and Cook, 1986), beds are further grouped into facies associations and related to depositional environments.

\subsection{Matrix-rich conglomerates (B1, B2, and B3)}

Three types of beds can be integrated in facies association 1 (FA1).

Polygenic limeclast beds (B1) correspond to thick ( 8 to $12 \mathrm{~m}$ ) deposits exposing large (up to $30 \mathrm{~cm}$ across) poorly-sorted carbonate clasts in a muddy calcilutitic matrix (Figs. 3, 4). Lithified clasts exposing both neritic (abundant benthic foraminifera and rudists) and slope contents (planktonic foraminifera, cherts, fragments of calcarenitic laminated beds) testify of uphill erosion. The lack of erosional features associated to sheet-like morphologies and relatively high matrix proportions suggest a cohesive behavior and freezing depositional mechanism relating these deposits to debris flows (Mulder and Alexander, 2001).

Polygenic graded beds (B2) refer to 2 to $10 \mathrm{~m}$ thick deposits exposing various platform debris (including coarse rudist debris and bioclasts) and well-sorted grainy slope particles (calcarenites to calcirudites) within a well-defined graded succession (Fig. 4). Load features and pillar structures are regularly present at the base. They are associated to hyperconcentrated density flows (Mulder and Alexander, 2001).

Muddy debrite beds (B3) expose 2 to $8 \mathrm{~m}$ of non-graded sediments containing a high-proportion of calcarenites and calcilutites. Outsized cherts and lithified platform clasts are sporadically associated to the deposit (Figs. 3, 4). Creeping features (Mulder and Cochonat, 1996) plus pillar structures at the base of the deposit testify of a cohesive behavior influenced by matrix strength (Mulder and Alexander, 2001).

Fig. 2. Regional correlation connecting the outcrops of the Cika Belt in the West (Tragjas, Piluri, Saranda and Ksamil) and the Kurveleshi Belt in the East (Zervati, Muzina and Vanister). See Fig. 1 for outcrop locations. For each outcrop the litholog representation displays: i) the type of sedimentary bed (summarized at the bottom right) with associated granulometry (notice that for facies associations (FA) 5 and 6, thicknesses of the beds are not respected); ii) syn-sedimentary features, characterized with six individual patterns, see text for explanations: iii) coarsening and thickening upwards trends. Timing of deposition is presented to the left, based on biostratigraphy using pelagic foraminifera. Numerical ages obtained with chronostratigraphic analysis are directly reported in bold to the left side of lithologs. Data obtained in Dhuvjani (Table 1) can also be used in Muzina since the outcrops are 6 km apart from each other and display the same pattern of deformed and undeformed strata. Phosphatic-rich horizons 1 and 2 are represented for Zervati and Vanister outcrops since they are continuously reported in the Mali Gjere (Fig. 1C). For Piluri, Saranda and Muzina outcrops, observation is regularly hampered by vegetation on the two phosphatic-rich horizons. Notice the designation of the sediment packages given in the simplified succession to the right. Abbreviations: CEN., Cenomanian; TUR., Turonian; CON., Coniacian; S., Santonian; PAL., Paleocene; BIO., Biostratigraphy; CL, Calcilutites; CC, Calcarenites; CR, Calcirudites.; F.A., Facies associations; SIS, Strontium Isotope Stratigraphy. 


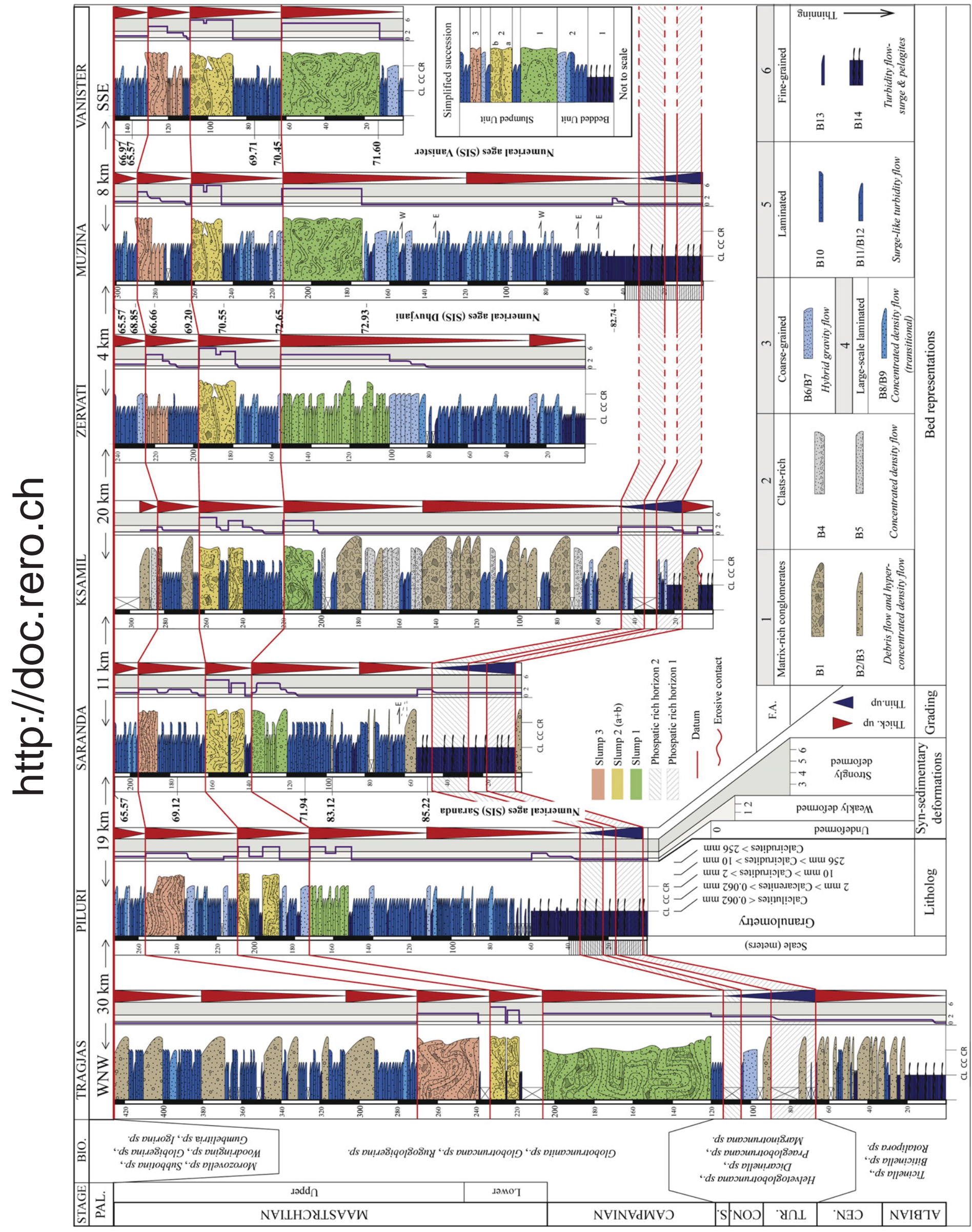



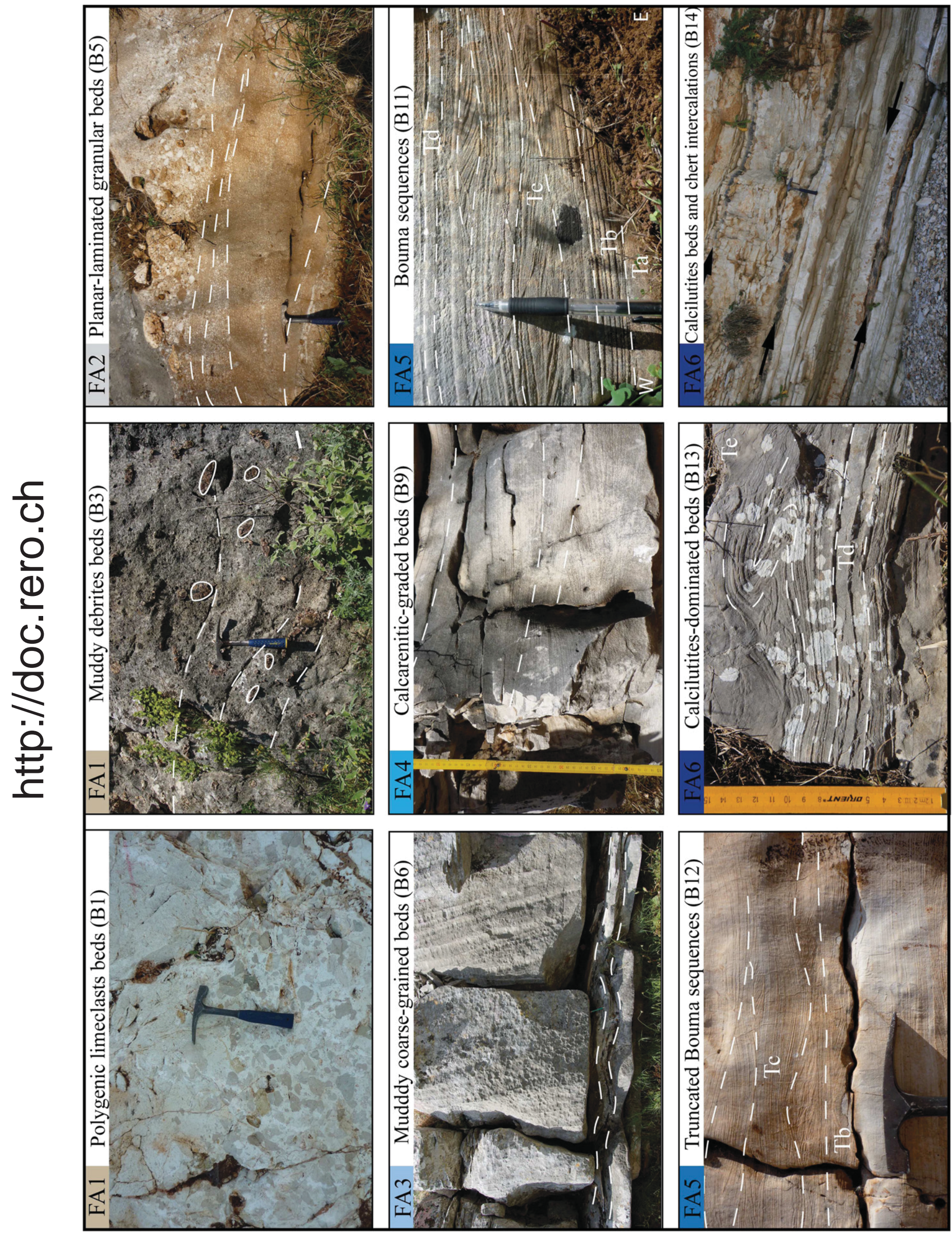


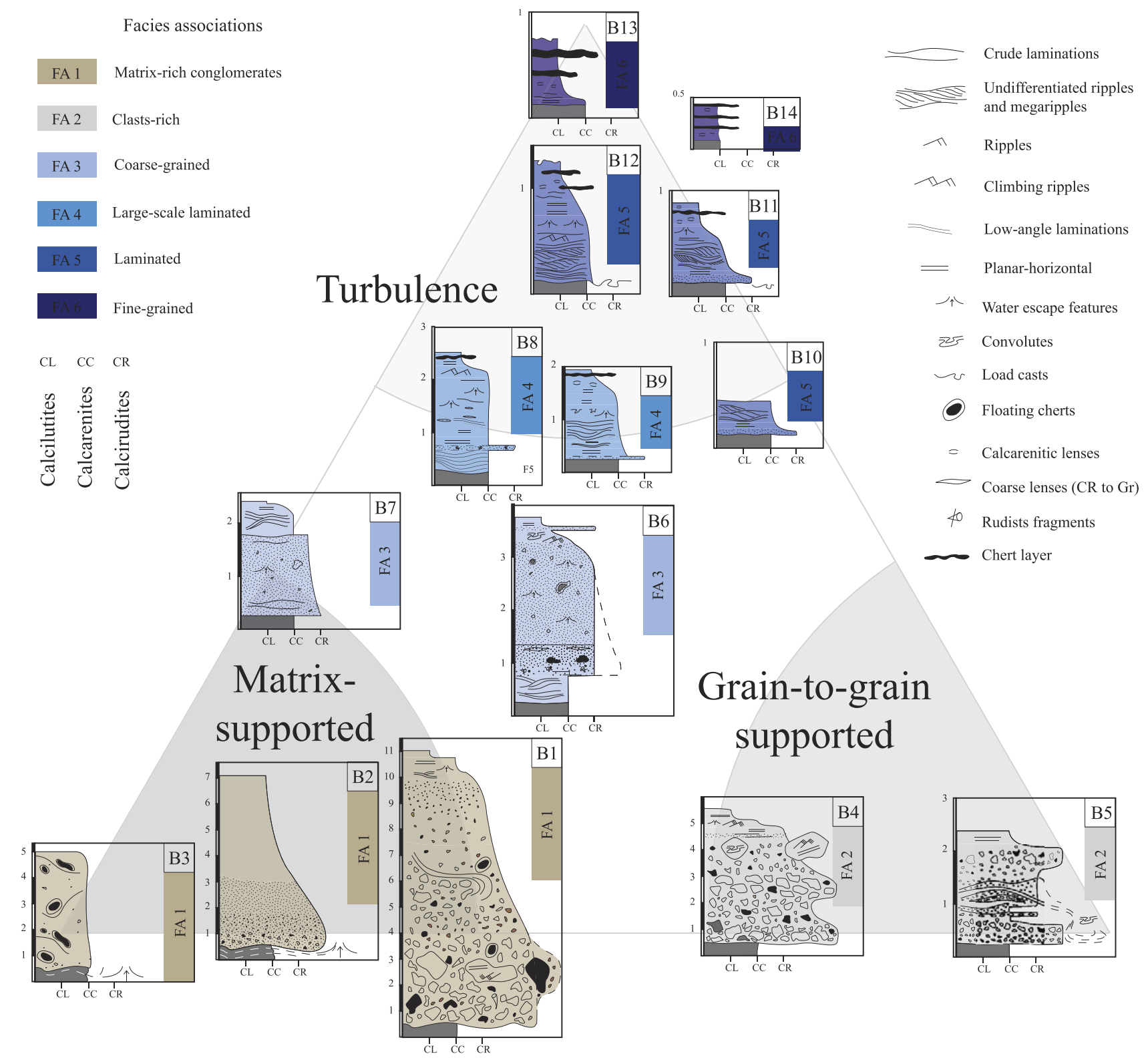

Fig. 4. Identified small-scale gravity-flow sequences defined based on field investigations. Emplacement within the three-axis diagram related to the dominant transport processes. The grey bed under the sequences is undifferentiated. Notice the differences in vertical scales given in meters.

\subsubsection{Depositional environment of FA1}

Similar deposits have been reported along bank/reef carbonate margin scarps as well as from inner apron settings (Facies $\mathrm{F}$ of Mullins and Cook, 1986; Colacicchi and Baldanza, 1986). Occurrences of such facies are more restricted in outer apron settings.

\subsection{Clasts-rich deposits (B4, B5)}

Two types of beds can be integrated in facies association 2 (FA2).
Clast-rich conglomerate beds (B4) are exposed in 3 to $6 \mathrm{~m}$ thick deposits. Alternatively graded and inversely grading successions with pronounced horizontal fabric of pebbly sub-rounded clasts $(2-10 \mathrm{~cm}$ across) make up the deposit, while matrix is of minor importance (Fig. 4). Vertical-size segregation attests of non-cohesive transportation of the grains, referring to concentrated density flows (Mulder and Alexander, 2001).

Planar-laminated granular beds (B5) (2-3 m in thickness) document decimeter to pluri-decimeter thick sheet-like stacking of frequently inversely graded layers with numerous grain-size breaks (Figs. 3, 4) and major disturbances such as large-scale convolutes. Sedimentary

Fig. 3. Few examples of the facies recognized in the field, from top to bottom and left to right: Polygenic limeclasts (B1); Muddy debrites (B3), note encircled platform clasts and cherts. Dashed lines stand for crude laminations observed in the bed; Planar-laminated granular beds (B5), note the laminations (dashed lines) underlining the vertical-size segregation of particles; Muddy coarse-grained beds (B6), note the segregation into a basal, calcarenitic laminated part (dashed lines) and the poorly-graded upper part of the deposit. Thickness of the bed is about $1.5 \mathrm{~m}$; Calcarenitic-graded beds (B9), note the large scale laminations underlined by dashed lines, thickness of the bed is $45 \mathrm{~cm}$; Bouma sequence (B11), with subdivisions characterized by specific sedimentary structures Ta, b, c, d, or Bouma terminology (1962), and the eastwards migration of ripples features; Truncated Bouma sequence (B12), note the sedimentary structures consisting in planar laminations ( $\mathrm{Tb}$ term) and ripples-like features (Tc): Calcilutites-dominated beds (B13), note the laminations at the base (Td) and convolutes at the top (Te), thickness of the bed is $15 \mathrm{~cm}$; Calcilutites beds and chert intercalations (B14), note the regular alternations of white hemipelagites, dark chert layers (arrows to the right) and green argillites (arrow to the left). 
structures point to grain-to-grain and grain-to-bed interactions during deposition, referring to a concentrated density flow (Mulder and Alexander, 2001).

\subsubsection{Depositional environment of FA2}

Similar facies are documented from upper slope and inner apron environments by Mullins and Cook (1986), where they are identified as facies $\mathrm{A}$.

\subsection{Coarse-grained deposits $(B 6, B 7)$}

Two types of beds can be integrated in facies association 3 (FA3). They are described as pebbly/cobbly sequences in Rubert et al. (2012).

Muddy coarse-grained beds (B6) (2 to $5 \mathrm{~m}$ in thickness) comprise poorly graded calciruditic particles. Load-casts and outsized clasts usually made up of cherts regularly occur. The base of the deposit may display large-scale laminations and/or spaced-planar laminations in a clean calcarenitic interval (Figs. 3, 4). This deposit is interpreted as a hybrid gravity-flow (Davis et al., 2009; Haughton et al., 2009) comprising a concentrated density flow at the top and a clean laminated calcarenitic layer at the base (Haughton et al., 2009).

Muddy beds (B7) with crude laminations make up 1 to $2.5 \mathrm{~m}$ thick deposits exposing a basal coarse part displaying crude laminations. The upper part regularly documents large scale megaripples within a calcarenitic granulometry (Fig. 4). These beds are assigned to a concentrated density flow (Mulder and Alexander, 2001) with a poorly cohesive behavior at the base and surge-like turbidity flow at the top formed by progressive dilution of the upper part (Hampton, 1972; Fisher, 1983; Talling et al., 2012).

\subsubsection{Depositional environment of $F A 3$}

Comparable deposits are described as pebbly calcarenites by Mullins and Cook (1986; facies A), exposing a basal debris flow and upper turbiditic cap (Hampton, 1972). They are mostly found in outer apron settings (Mullins and Cook, 1986).

\subsection{Large-scale laminated deposits $(B 8, B 9)$}

Two types of beds can be integrated in facies association 4 (FA4). They are described as large-scale lamination sequences in Rubert et al., 2012.

Large-scale laminations compose the base of calcarenitic-dominated beds (B8). After a grain-size break, the overlying part is composed of a thin poorly sorted coarse calciruditic interval containing a high proportion of rudist fragments. A slight normal grading trend is documented upwards where calcarenites exposing planar laminations predominantly occur (Fig. 4). Slight granulometric alternations evidence of postsedimentary load-effects disturbing the original planar-lamination structures. The medium to coarse grain-size of the material, relatively good sorting and thickness of the bed suggest a concentrated density flow. However, the development of ripple-like structures at the top suggests a turbulent support mechanism of the grains (Mulder and Alexander, 2001).

Calcarenitic-graded beds (B9) expose a well-defined normal grading present all over the vertical extension of the deposit ( 1 to $2 \mathrm{~m}$ thick), exposing alternations of planar-horizontal and large-scale crosslaminations made of calcarenitic material (Figs. 3, 4). The uppermost part of the deposit exposes calcarenite-rich load-casts and convolute laminations followed upwards with calcilutites commonly associated with in-situ chert layers. Rich-laminations and calcarenitic particles
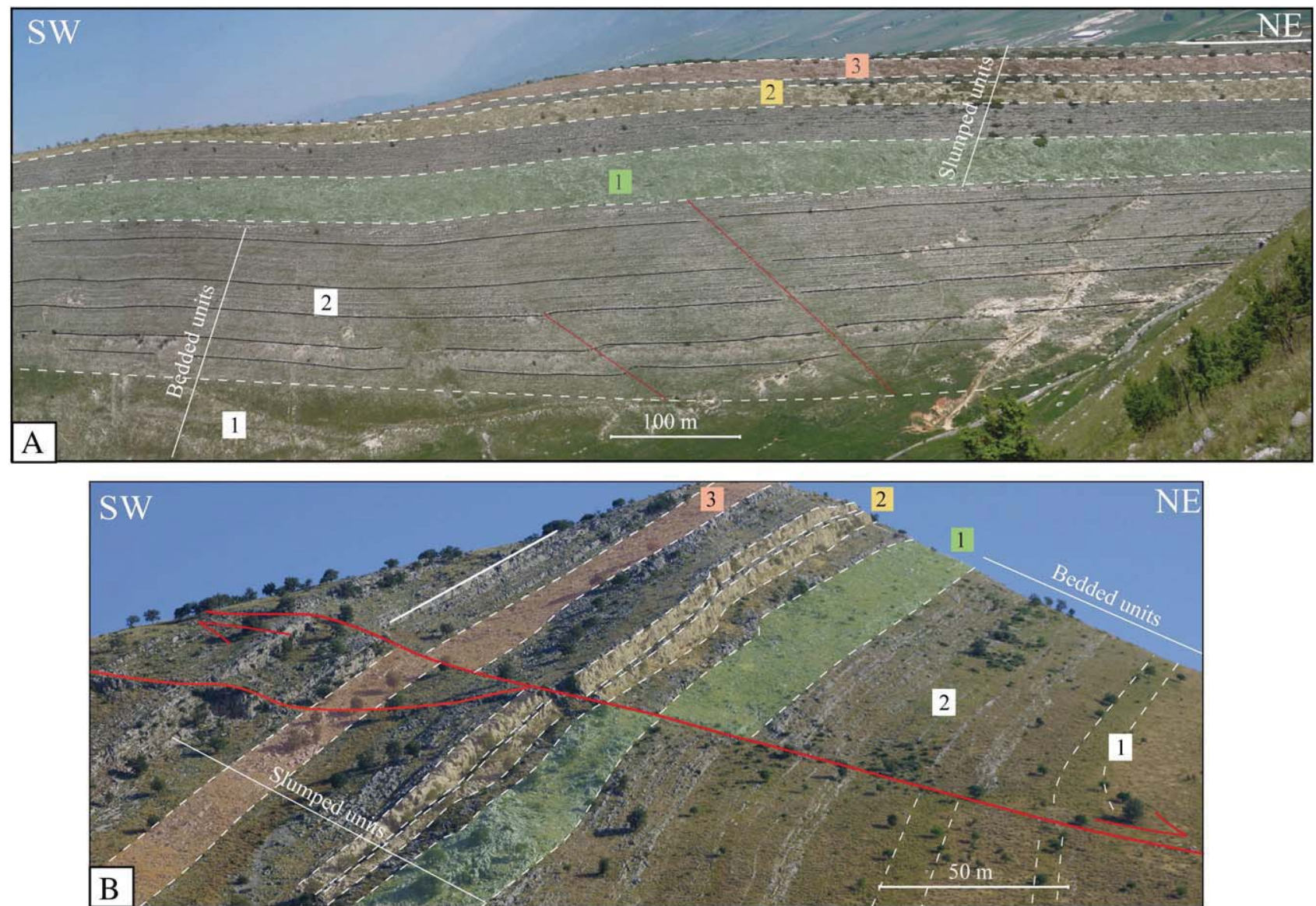

Fig. 5. (A) Outcrop picture of the Grapsh valley (Muzina) with identified sediment intervals (bounded by dashed lines) mentioned in the text and in Fig. 2; (B) Outcrop picture of the Grapsh valley (Muzina) with identified sediment intervals (bounded by dashed lines) mentioned in the text and in Fig. 2. 

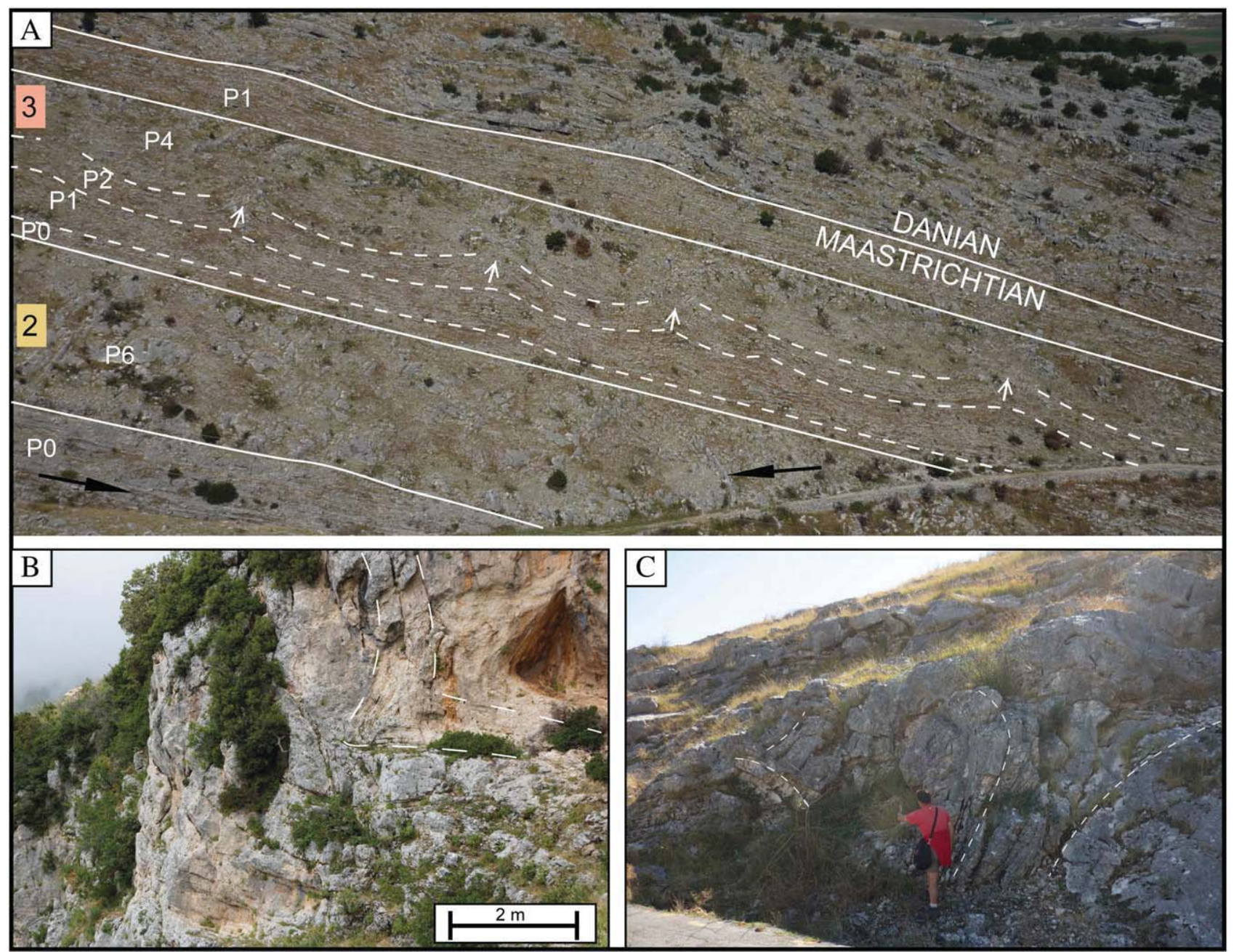

Fig. 6. (A) Example of stacking of different patterns in the Muzina succession, numbers 2 and 3 refer to slumped units 2 and 3 respectively, deformation patterns (P0 to P6) are mentioned for each interval. Note the well-bedded pattern in the lower part of the picture (P0, arrow to the right), and discontinuous limbs (P6, arrow to the left) in an overall disturbed pattern with rare discontinuous limbs. P0 P1 and P2 show an increasing deformation and destruction of the bedding upwards, broadly documented for P4 Pillar structures are indicated by small white arrows. Weakly deformed layers are present above the slumped unit 3; (B) Syn-sedimentary folding (slump) in the Upper Cretaceous succession (Tragjas outcrop), illustration of the pattern 3 (P3). Note the consistency of the bedding attesting a coherent type of syn-sedimentary deformation, see text for explanations (C); Syn-sedimentary deformations attested by a chaotic layout showing heavy contorted sediment packages, folds and discontinuous limbs, illustration of the pattern 5 (P5).

attest of mixing and dilution of the flow (Talling et al., 2012) and turbulent support of the grains. These beds are assigned to a concentrated density flow (Mulder and Alexander, 2001).

\subsubsection{Depositional environment of FA4}

These deposits are related to well-graded sequences, similar to facies A as described in Mullins and Cook (1986). Dilution and mixing of debris flows evidenced by ripple and parallel laminations relate them to an outer apron setting.

\subsection{Laminated deposits (B10, B11, B12)}

These beds refer to relatively thin deposits (few decimeter to more than one meter thick), rich in sedimentary structures. Three types of beds can be integrated in facies association 5 (FA5).

B11 is described first as it allows further definition of B10 and B12. B11 displays a wide range of sedimentary structures and a grading upwards trend. From the base to the top, a centimeter-scale calciruditic interval reveals crudely sorted particles, rapidly evolving upwards into a planar-laminated interval. The latter is overlain by a rich-laminated interval exposing undulated and ripple structures (Figs. 3, 4). Convolute laminae regularly occur at the top, followed by planar horizontal laminae and a calcilutitic interval commonly displaying discontinuous or continuous in-situ chert layers. These beds (B11) are named coarsegrained sequences in Rubert et al. (2012). Truncated beds (B10) are devoid of one or several upper intervals described in B11 while base cutout beds (B12) do not display the bottom part of the set described in B11. Beds of B11-type can readily be described according to the Bouma divisions (1962) and are associated to classical carbonate turbidites displaying a full Bouma sequence (Bouma, 1962; Mullins and Cook, 1986; Eberli, 1991) as mentioned in Rubert et al. (2012). Missing upper terms (Tc-e) in B10-beds and basal terms (Ta-b) in B12-beds (Figs. 3, 4) relate these facies to truncated and base cutout Bouma sequences respectively (Bouma, 1962). They are associated to surge-like turbidity flows (Mulder and Alexander, 2001).

\subsubsection{Depositional environment of FA5}

B10 and B12 beds are recognized in outer apron settings, referring respectively to facies A and D of Mullins and Cook (1986) while B11 (facies C of Mullins and Cook, 1986) can be found in inner apron settings subordinate to mud-supported conglomerates and clasts supported conglomerates. 


\subsection{Fine-grained deposits (B13 and B14)}

Two types of beds can be integrated in facies association 6 (FA6). They are described as fine-grained sequences in Rubert et al. (2012).

Calcilutite-dominated beds (B13) refer to thin deposits (few centimeter to one meter) comprising parallel laminations at the base made of thin granulometric alternations. Convolute laminations are regularly associated with the parallel laminations (Figs. 3, 4). The upper part of the deposit exposes thin calcilutitic deposits regularly displaying elongated mud-lenses and in situ chert layers. Load-casts are frequently present within the uppermost part, derived from the overlying deposit. These beds are interpreted as turbidity flow-surges (Mulder and Alexander, 2001), and related to Stow-type turbidites (Stow and Shanmugan, 1980).

B14-beds consist of thin (several to ten centimeter thick) calcilutite interbeds with well-developed continuous in situ chert layers and clay (Figs. 3, 4). Radiolarians are regularly evidenced together with pelagic foraminifera. These facies are interpreted as background sedimentation in Rubert et al. (2012). These intervals evidence a decantation process related to mud deposition and in situ silicification in relation to a diagenetic overprint (Eberli, 1991).

\subsubsection{Depositional environment of FA6}

Fine-grained to muddy facies are found in upper apron settings around canyons as well as in basin plain (Facies G sensu Mullins and Cook, 1986). Interbedding of muddy deposits with chert intercalations and clay (B14) typically suggests deep basinal settings (Eberli, 1991).

Our data compared with the carbonate facies of the Bahamas allowed proposing the following depositional environments for each facies association (FA). FA1 is associated to margin/inner apron settings, FA2 to inner apron settings, FA3 and FA4 to outer apron settings, FA5 to undifferentiated apron settings and FA6 to basinal settings. According to the vertical sequences described for each bed, a main grain support mechanism is identifiable for each facies association (FA). Matrix support and grain-to-grain interactions predominantly occur for the settling of inner apron deposits (FA1, FA2) while outer apron settings report an increasing influence of turbulence (FA3, FA4, FA5 and FA6). Fig. 4 schematically illustrates the main support mechanism governing the grain transportation along the carbonate slope. Inner apron deposits are represented at the base of the three-axis diagram, while outer apron deposits are represented at the top (Fig. 4).

\section{Slumps}

"Submarine slides (or slumps) represent semi-consolidated sediment that has moved variable distances basinward along discrete basal shear planes" (sensu Mullins and Cook, 1986). The high potential of these thick intervals (several tens of meters in thickness) for stratigraphic correlations (Fig. 2) in the Upper Cretaceous deposits of Albania justifies to pay particular attention to them. Large-scale deformations of single-bed packages displaying an overall disturbed pattern $(\mathrm{P})$ such as thrust or fold morphologies were recognized. The different deformation patterns (P1 to P6) shown in Figs. 5, 6 suggest a syn-sedimentary origin (Spalluto et al., 2007; Aslop and Shmuel, 2011). They are described below together with the assumed deformational processes. These deformed strata are inserted within well-bedded intervals (Figs. 2, 5, 6A), which are only affected by late orogenic tectonics, thus documenting no syn-sedimentary deformation (P0).

\subsection{Weakly deformed layers}

\subsubsection{Pattern 1 (P1)}

A weak wavy undulation displaying a meter to pluri-meter wavelength pattern characterizes this feature identified under slumped units. Dome-like structures form at regular distances (ten to several tens of meters) and alternate with concave-up shapes conveying the deformation to underlying beds (Fig. 6A).

\subsubsection{Pattern 2 (P2)}

Large concave and convex structures characterize this pattern associated with stretching of the beds resulting in limb failures. Pillar structures (Fig. 6A) and gliding surfaces are recognized, implying thrusting of pluri-meter thick sediment packages. Polarity and consistence of the beds are respected.

Both patterns (P1 and P2) attest to slight reworking of the layers increasing upwards, suggesting a coherent type of deformation (Corbett, 1973). No or weak displacement of the layers is attested basinward, thus suggesting in-situ reworking. Thick packages of strongly reworked sediment are commonly evidenced above these intervals (Fig. 6A) while the underlying layers expose a well-bedded pattern (P0). This characteristic documents a progressive involvement of the layers induced by fold amplification (Corbett, 1973; Aslop and Shmuel, 2011).

\subsection{Strongly deformed layers}

\subsubsection{Pattern 3 (P3)}

Deformational features are exposed in a coaxial dominated fold style (Aslop and Shmuel, 2011) reworking thick packages (up to $100 \mathrm{~m}$ ) of sediment layers. Consistency of the bedding is mainly preserved within the fold framework. Evidences of compaction features are reported (Fig. 6B).

\subsubsection{Pattern 4 (P4)}

Multi-layer slumped successions expose a non-coaxial (asymmetrical) dominated folding (Aslop and Shmuel, 2011) with a general continuity of the layers. Evidences of recumbent folds (Farell, 1988) and overturned limbs regularly occur. Complex folding associated with heavy stretching are documented and reflect failures of the limbs. Chaotic zones where bedding is no more defined locally occur (Fig. 6A).

\subsubsection{Pattern 5 (P5)}

A general disorganized and chaotic layout conspicuously characterizes this pattern. Heavily contorted layers and isolated fold cores (Corbett, 1973) compose these reworked packages which are several tens of meters in thickness. Rafted limbs (Rubert et al., 2012) and limb failures are widely documented throughout the deposit (Fig. 6B).

\subsubsection{Pattern 6 (P6)}

Bottleneck structures or "boudinage" of the layers (Elliot and Williams, 1988) are associated to this deformation pattern, also associated with sub-horizontal lenses (Corbett, 1973). Creeping features (Mulder and Cochonat, 1996) are coupled with rare fold and discontinuous limbs of consistent gravity-flow deposits (Fig. 6A).

Patterns 3 to 6 evidences different deformation processes that affected well-bedded packages of gravity-flow deposits (P0). P3 is related to horizontal shortening (Aslop and Shmuel, 2011) and is characterized by consistency of the layers (Fig. 6B) referring to a coherent type of deformation (Corbett, 1973). By the diverse nature of the P4, P5 and P6 deformations, they document respectively local, general and complete dismantling of the unconsolidated layers attesting semi-coherent to incoherent behaviors (Corbett, 1973). Dismantling processes are closely related to the increase of pore pressure within water-saturated materials (Owen, 1987; Spalluto et al., 2007). The loss of shear resistance is evidenced within the slumps with amplification of folding (Aslop and Shmuel, 2011), disaggregation (Corbett, 1973), or liquification (Farell, 1988), progressively leading to the destruction of bedding.

\section{Field $\log$ analysis}

This part aims to describe the sedimentary record of seven individual outcrops (Fig. 1C). In order to avoid a lengthily description of each 
succession, several of them have been grouped. Four outcrops (Tragjas, Piluri, Saranda and Ksamil) belong to the Cika Belt (Fig. 1B, C). Ksamil and Tragjas successions will be described together, as they both display thick successions (430 and $310 \mathrm{~m}$ respectively) of coarse deposits (FA1, FA2, Fig. 2). Saranda and Piluri successions, exposing thinner successions (210 and $275 \mathrm{~m}$ respectively) of predominantly calcarenitic/ calciruditic laminated deposits (FA3 to FA5, Fig. 2) will also be described together. The last description stands for the outcrops of the Mali Gjere Mountains situated on Kurveleshi Belt (Fig. 1B, C).

The following descriptions will regularly refer to two units (Fig. 2) recognized in every outcrop, namely: i) a bedded unit referring to well-bedded strata composed of two distinctive parts (1 and 2) and ii) a slumped unit referring to the strata comprising syn-sedimentary deformations (1, 2, and 3, Fig. 2).

\subsection{Ksamil and Tragjas sections}

In the lower part of the Ksamil section, thickening upward muddy debrites (B3, Fig. 3) are typically intercalated in background sedimentation composed of calcilutites alternating with chert interbeds (B14, Figs. 2, 3) and centimeter-like argillite intervals. Phosphate-rich deposits associated with hemipelagites, radiolarites (B14, Fig. 3) and calcarenites make up two regular intervals easily noticeable in the landscape due to the presence of bushes and trees. Unfortunately these intervals are poorly exposed due to pedogenesis. Syn-sedimentary deformation patterns P1 and P2 are reported within the succession (Fig. 2). In Ksamil, a slight erosional contact is evidenced between bedded units 1 and 2 (Fig. 2). Matrix-rich conglomerates (B1, B3), clast-rich conglomerates (B4, B5) and laminated beds (B11, B12) mainly compose the sedimentary record (Fig. 2). The vertical stacking of sedimentary beds suggests different orders of thickening upward trends $(30 \mathrm{~m}$, $100 \mathrm{~m}$, Fig. 2). Evidences of deformations are widely documented in the slumped unit (Fig. 2). Strongly deformed levels (slumped units 1 , 2 (a, b) and 3) alternate with undeformed and weakly deformed strata (Fig. 2). The slumped unit 1 is the first syn-sedimentary deformed package (Fig. 2) consisting of 15 to $20 \mathrm{~m}$ of strongly reworked deposits (P4) composed of pebble-like polygenic clasts. Both platform and slope debris components are recognized in thin sections. Weak deformations (P1) are reported under the slumped unit 1 suggesting a progressive damping of the deformation within the underlying layers (Ksamil, 200-205 m, Fig. 2). Above the slumped unit 1, the Ksamil succession exposes alternations of thin turbiditic deposits mainly composed of truncated Bouma sequences (B10), followed by two consecutive slumped levels or debris flows (slumped unit 2, a and b, Fig. 2). The latter reveals polygenic calciruditic fragments with an important proportion of neritic fauna (rudists, Orbitoites, Miliolidae). The uppermost part of the Maastrichtian reports consecutive slumped and major debris flows which unfortunately are poorly exposed.

In Tragjas, the bedded unit 1 (Fig. 2) shows similar features compared to Ksamil, namely muddy debrites (B3, Fig. 3) inserted in hemipelagites, exposing rounded lithified clasts, up to $10 \mathrm{~cm}$ across and containing benthic foraminifera and broken rudist shells. In-situ deformations (P1 and P2) widely affect phosphatic-rich deposits (85-116 m, Fig. 2). After a few meters of laminated beds (B11, B12) displaying in-situ deformations (Fig. 2) the slumped unit 1 occurs. The latter dominantly displays calciruditic beds arranged in a parallel fold style (P3, Fig. 6B) and reaches up to $100 \mathrm{~m}$ in thickness. Two consecutive major syn-sedimentary deformed intervals (slumped unit 2, a and b) were identified above the first slumped interval (Fig. 2). They are composed of calciruditic material globally thinning upwards, and limited by thin undeformed low-density calciturbiditic deposits (B12, Fig. 2). A fourth major interval (30 m in thickness) composed of reworked calciturbiditic lithologies and exposing large scale gliding of thick sediment packages follows (P2, Fig. 2). This succession is capped by a thick undeformed succession (150 $\mathrm{m}$ in thickness) made of an alternation of laminated beds (B10, B11, B12) and polygenic graded deposits (B2).

\subsection{Piluri and Saranda sections}

The basal part of the Piluri succession consists of alternations of thin calcilutitic layers with chert-bearing interbeds (B14) and phosphaterich deposits. Minor syn-sedimentary deformations are present showing a progressive increase of the deformation upwards (P1 and P2, 35-60 m). Fine grained beds (B13) and laminated beds (B11, B12) progressively replace hemipelagites (B14), showing a clear coarsening and thickening upwards trend (Fig. 2). Occurrences of coarse deposits exist (B6, B7), regularly inserted within turbiditic dominated beds (Fig. 2). The slumped unit 1 was identified in Piluri between 152 and $172 \mathrm{~m}$, giving further detail to the field log presented in Rubert et al. (2012). It exposes syn-sedimentary fold packages (P4). Predominance of calciruditic components was evidenced within the slump, contrasting with underlying layers (Fig. 2). Above the slumped unit 1, the succession consists of several intervals exposing syn-sedimentary deformation structures of varying degrees (P1 to P5). Note that the increase of the deformation upwards is commonly associated to coarsening upwards trends (Fig. 2).

In Saranda, the base of the bedded unit 2 is marked by a 6 meter thick muddy debrite (B3) (not recognized in Piluri), exposing large chert fragments (up to $50 \mathrm{~cm}$ ) and progressively thinning eastwards (Fig. 2). Fine grained beds (B13) and laminated beds (B10, B11, B12) progressively replace hemipelagites (B14), also documenting a coarsening and thickening upward trend (Fig. 2). Muddy debrites (B3) are regularly evidenced, inserted in laminated beds (B10, B11, and B12). Note the regular existence of truncated Bouma sequences (B10) that suggest residual bypass deposits. The slumped unit 1 evidences a coarse nature of deposits (Fig. 2) and is immediately followed by two thick deformed intervals (slumped units 2 , and $\mathrm{b}$ ) barely separated by a thin package $(0.75 \mathrm{~m}$ ) of laminated beds (Fig. 2). Above the slumped unit 2, deposits are broadly exposing deformation patterns 1 and 2 (Figs. 2, 5B).

\subsection{Zervati, Muzina and Vanister sections}

Thin hemipelagitic deposits alternating with chert interbeds (B14) characterize the bedded unit 1, present in the lower part of the sections. Two phosphate-rich horizons are recognized along the Mali Gjere Mountains, attesting a great continuity over $35 \mathrm{~km}$ from SE to NW (Fig. 1B). Poor outcropping conditions are often associated with these vegetation-rich intervals. The contact between bedded units 1 and 2 is not obvious in the field, but in some large-scale outcrops an angular discontinuity may occur. Thin turbiditic deposits typically alternate with hemipelagites at the base of the interval (B12 and B13, Fig. 2) and progressively show grading into coarser and thicker deposits. Large-scale laminated (B8, B9) and massive coarse-grained beds (B6, B7) are reported around $70 \mathrm{~m}$ in Muzina and $20 \mathrm{~m}$ in Zervati (Fig. 2). Considering the absence of bottom marks (tool or scours marks, and flute casts), current directions could regularly be deduced on the basis of sedimentary features exposing unidirectional current evidences such as ripples. They show alternatively eastwards and westwards migration of the ripples depending on the beds, but such features can hardly be recognized for every single-bed. Some of the directions of ripple migration are shown in Fig. 2.

The slumped unit is composed of an alternation of undeformed intervals of laminated beds (B11, B12 mainly) and thick packages of coarse calciruditic-dominated deposits affected by varying degrees of deformation (Fig. 2). The stacking of undeformed and strongly deformed intervals is conspicuously exposed across the Mali Gjere mountains (Figs. 2, 5A), attesting a lateral continuity with minor thickness variations (Fig. 2). Slumped intervals consist of coarser material than wellbedded intervals. This is notably documented in Zervati for the slumped unit 1 (Fig. 2) where individual beds composing the reworked package are specifically reported. The slumped unit 1 (Fig. 2) documents strong dismantling processes affecting beds (P4). Some outcrops (e.g. Vanister, Muzina) reveal the presence of a peculiar bed with undulated base and 
flat top (Fig. 2) which is made of coarse material and filling irregularities derived from the arrangement of reworked beds (Rubert et al. 2012). Inter-slump packages show evidences of in-situ deformations (P1 and P2) progressively attesting of strong deformational processes upwards (Slumped unit 3, Figs. 2, 6A). Detailed sedimentological investigations carried out on the slumped unit 2 revealed the presence of a thin package of reworked beds (1-2 $\mathrm{m}$ in thickness) roughly dividing the slumped succession in two intervals reflecting successive events of reworking of an original slump (Aslop and Shmuel, 2011).

\section{Sedimentary evolution and model}

The development of a depositional slope model incorporating all data gathered in this study is hampered by a number of missing data which are the non preservation of the upper slope system connecting the Apulian platform to the Ionian Basin to the west, and the lack of information of the Kurveleshi belt (Fig. 1B) to the east. Nevertheless the data allow studying the sedimentation dynamics of the system, which is compared with published studies in Italy (Gargano and Murges areas, Borgomano, 2000; Spalluto and Caffau, 2010) and in Albania/ Greece (Aubouin, 1959; Skourtsis-Coroneou et al., 1995; Meço et al., 2000; Heba and Prichonnet, 2006, 2009; Karakitsios, 2013).

\subsection{Late Albian-Santonian}

In Albania, the studied successions reveal resedimented muddy debrites (FA1) of margin/inner apron settings (Tragjas and Ksamil) inserted in basinal hemipelagites alternating with in-situ chert-rich layers with abundant radiolaria (FA6) which were uniformly recognized in Zervati, Muzina and Vanister outcrops (Fig. 7). Similarities are evidenced with the Vigla limestone Formation (Aptian-Early Turonian) described in Greece, consisting of pelagic limestones and chert-bearing beds with radiolaria-rich beds (Aubouin, 1959; Skourtsis-Coroneou et al., 1995; Karakitsios, 2013). In Italy, the base-of-slope succession of the Gargano area exposes pelagic mudstones (Vico Formation, Lower Cretaceous) followed by bioclastic apron limestones (Monte San Angelo Formation, Middle Cenomanian-Lower Turonian) described by Borgomano (2000). The coarse and poorly-sorted muddy debrites (B3) recognized only in the Tragjas and Ksamil sections document short transportation of the platform-shed debris and a reworking of basinal deposits (FA6). Episodic collapses closely related to margin scarp (Mullins and Cook, 1986; Borgomano, 1987, 2000) are invoked to explain these destabilization events that likely were governed by an active shelf edge of the Apulian margin (Fig. 7).

The two regionally identified phosphate-rich horizons (Fig. 2) are Turonian to Santonian in age (Brahimi et al., 1987, 1992; Meço et al., 2000). Thin and similar thicknesses (10 to $20 \mathrm{~m}$ each, Fig. 2) are associated to these horizons, testifying of low sedimentation rates during this period, and the absence of significant sediment influx from the platforms. A starvation of the basinal system is documented during this period. Hemipelagites and phosporites are recognized throughout the entire studied area for this time interval, attesting of deep-basinal sedimentation (Fig. 7). Rich-organic black shale horizons (Karakitsios, 2013) and phosphorites (Aubouin, 1959; Skourtsis-Coroneou et al.,

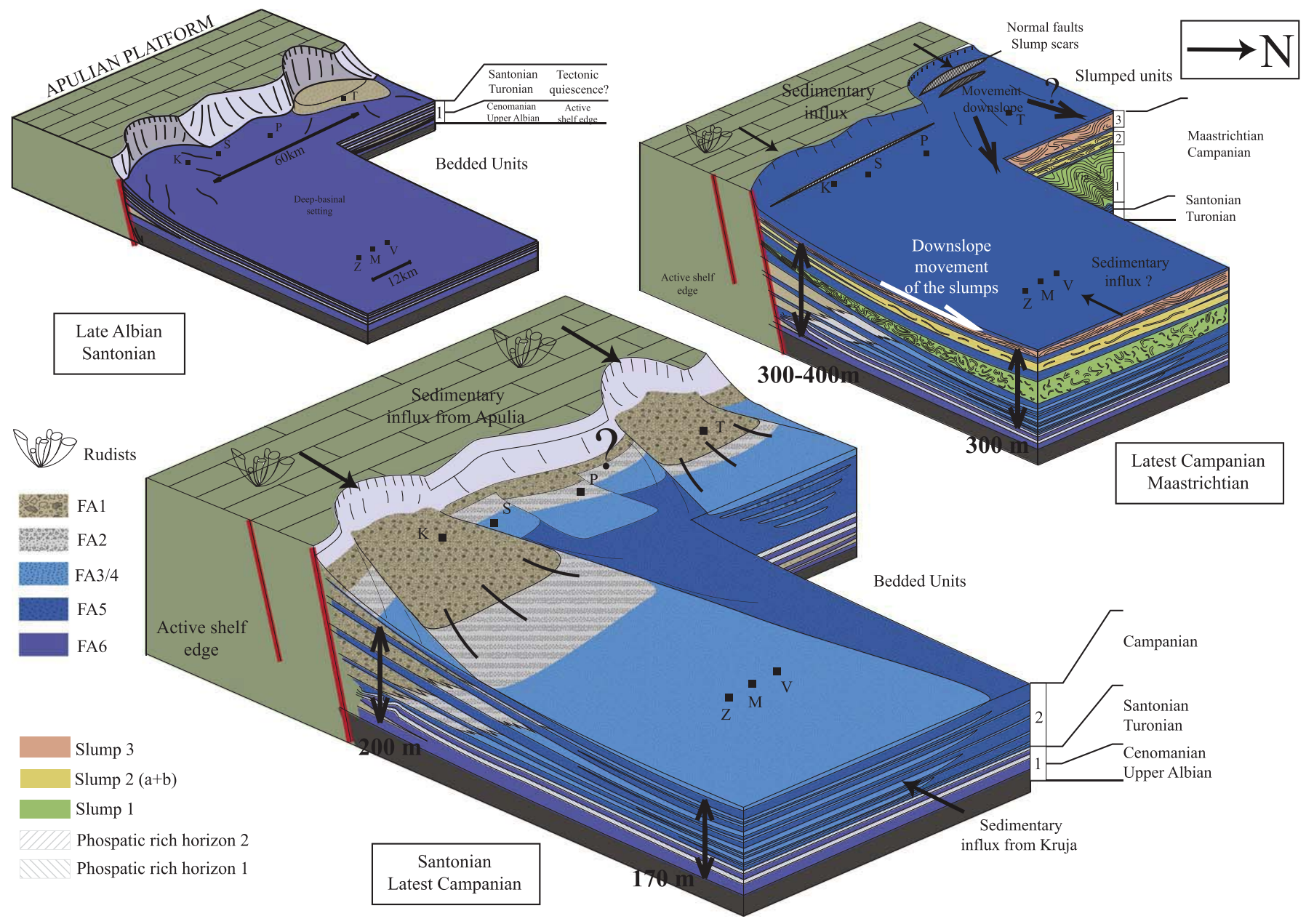

Fig. 7. Possible paleogeographical evolution of the western part of the Ionian Basin during the Upper Cretaceous. Abbreviations: T, Tragjas; P, Piluri; S, Saranda; K, Ksamil; V, Vanister; M, Muzina; Z, Zervati; FA, Facies association; km, kilometer; m, meter. 
1995; Meço et al., 2000) are reported during this period in the Greek Vigla Formation. They are related to global Oceanic Anoxic Events (Skourtsis-Coroneou et al., 1995; Karakitsios, 2013). In Italy, a sedimentary hiatus is identified in the slope to basinal succession of the Gargano area during the Turonian (Borgomano, 2000). It is associated with subaerial exposure of the platform and bauxitic development during lowstand (Borgomano, 2000; Spalluto and Caffau, 2010) responsible for the settling of carbonate breccias in the toe-of-slope setting (Nevarra formation). Muddy debrites (B3) and turbidites (Fig. 2) that are sparsely intercalated in hemipelagites in the Ksamil and Tragjas outcrops suggest a persistence of instabilities at the platform edge and preferential sediment accumulation in the inner apron setting (Fig. 7). Instabilities due to the subaerial exposure of the platform are invoked to explain the deposition of carbonate breccias during sea-level falls (Spence and Tucker, 1997, Reijmer et al., 2012). The ante-Santonian period is regarded as a stability period in Kruja (Heba and Prichonnet, 2009) characterized by the development of neritic sedimentation.

\subsection{Santonian-Latest Campanian}

Sedimentological observations coupled with bio- and chronostratigraphic results evidenced a significant sedimentary evolution during the Santonian. Abrupt settling of resedimented muddy debrites (FA1) is observed in Saranda and Ksamil (Fig. 2), while laminated beds (FA5) progressively overlay fine-grained beds (FA6) in other outcrops (Piluri, Zervati, Muzina and Vanister, Figs. 2, 7). Ripple-like features studied in Muzina document a sediment influx derived from both westwards and eastwards directions during this period. However, more specific investigations are needed to assess in a quantitative way sediment thicknesses that were derived respectively from Kruja and Apulia. This approach could be interesting to explain discrepancies in terms of sediment accumulations for the Saranda (210 m, Figs. 2, 5B) and the Muzina successions (305 m, Figs. 2, 5A). Syn-sedimentary deformations are reported at the base of the gravity-flow deposits (P1 and 2, Fig. 2) that are synchronous with this significant change of sedimentary dynamics. An increasing tectonic activity is most likely responsible for this abrupt change in the sedimentary dynamics and the resedimentation of coarse (up to ten centimeter) clasts (Miliolidae-rich or rudists packstones) associated to margin/inner apron settings. Tectonic instabilities recognized within the Santonian carbonates on the Kruja Platform (Heba and Prichonnet, 2009) possibly correlate to these destabilization features that are of regional significance. The described beds (B1 to B14) attest sheet-like morphologies with no evidence of channelized or erosive features. Line-source apron-like models devoid of channel-feeder have been invoked to explain this characteristic of carbonate slopes (Mullins and Cook, 1986; Colacicchi and Baldanza, 1986; Eberli, 1991 among others), suggesting a similar distribution of sediments along the base-of-slope margin. However, our study testifies of a different nature of deposits in the Tragjas, Piluri, Saranda and Ksamil area (Figs. 2, 7), even though they are related to the same Cika thrust belt (Moisiu and Gurabardhi, 2004) associated to the same paleogeographical setting (Fig. 1). Matrix-rich conglomerates (FA1) exposed in Ksamil are uncommon in Saranda (Fig. 2) despite the fact that the two outcrops are only $11 \mathrm{~km}$ separated from each other. Although sedimentary observations were limited to synsedimentary structures, Campanian deposits in Tragjas expose large lithified platform clasts, contrasting with dominantly laminated beds (FA5) observed in Piluri (Fig. 2). Thus, our observations reflect discrepancies regarding the uniform sedimentary influx along the Apulian margin in Albania (Figs. 2, 7). In Italy, a progressive reduction of the topographic margin scarp is mentioned for Santonian and Lower Campanian strata, which correlates with a fining upward trend reflected in the size of resedimented clasts (Borgomano, 1987, 2000). In Greece, a massive influx of clastic material into the basin is reported since the Campanian (Skourtsis-Coroneou et al., 1995). This trend agrees with the deposition of microbreccia limestones with abundant rudist fragments reported in the external zones of the Ionian Basin (Parga and Margariti units, Aubouin, 1959). Consequently, the sedimentation dynamics from Santonian to Uppermost Campanian is likely related to a tectonic activity responsible for the episodic dismantling of the Apulian and Kruja Platforms. However, this massive sedimentary influx during Santonian-Campanian times also corresponds with a high productivity upon the Apulian platform. $700 \mathrm{~m}$ of Senonian limestones are reported in the Apulian succession of the Sazani zone (Brahimi et al., 1992; Meço et al., 2000) while up to $500 \mathrm{~m}$ of rudist-dominated deposits are recognized in Kruja (L'escalier section; Heba and Prichonnet, 2009). This sedimentation is expressed on the Apulian platform by so-called "openingupwards sequences" described by Borgomano (2000) showing a gradual decrease of environmental restrictions. Similar trends are reported in the peri-Adriatic domain, attested by the expansion of rudist communities (Carannante et al., 1998; Simone et al., 2003; Heba and Prichonnet, 2006). This massive bioclastic production could be related to highstand shedding of carbonate platforms as described by a number of authors (Droxler and Schlager, 1985; Eberli, 1991; Schlager et al., 1994; Betzler et al., 1999; Borgomano, 2000). Coarsening and thickening upward sequences express a clear progradation of the Apulian platform basinward (Figs. 2, 7) during this period.

\subsection{Latest Campanian-Maastrichtian}

Since the Upper Campanian, the studied successions (Fig. 2) reveal an alternation of thick gravity-flow sediment packages which suffered variable degrees of syn-sedimentary deformations. Several reworking events of thick sediment packages were recognized in the studied successions (Slumped units 1 to 3, Figs. 2, 7). A similar timing of deformation confirmed by bio/chronostratigraphic data and physical correlations (Fig. 2) suggests a synchronal nature of destabilization events within inner and outer apron settings. Coarse sediments (FA1, 2, 3, and 4 in the Piluri, Saranda and Zervati outcrops, Fig. 2) mainly compose the reworked and displaced layers affected by strong deformations (P3 to P6, Fig. 2) while underlying strata are mainly composed of laminated beds (FA5, Fig. 2). Considering that each slump displaces carbonate material from an inner to an outer setting, each interval composed of wellbedded layers and overlying slumped layers reflects a coarsening and thickening upward sequence (Fig. 2). Deformations observed in the respective slumped intervals ( $\mathrm{P} 3$ towards P6, Fig. 2), support an increasing involvement of strong reworking processes eastwards, thus reflecting a west to east transportation of the resedimented material. The slump intervals show thicknesses variations depending on outcrop positioning within the basin (Figs. 2, 7). The first slump documents an important reduction of layer thicknesses depending on the outcrop location within the Cika belt (e.g. $100 \mathrm{~m}$ in Tragjas, less than $20 \mathrm{~m}$ in Ksamil, Figs. 2, 7), while similar thicknesses are exposed in the Kurveleshi Belt (50 to $70 \mathrm{~m}$ in Vanister, Muzina and Zervati). Similar trends in thickness variations are observed for the slumped units 2 and 3, i.e. a maximum thickness of reworked layers in Tragjas, with a downslope movement (Vanister, Muzina and Zervati, Figs. 2, 7) and attenuation laterally, to the south-east (Piluri, Saranda and Ksamil, Figs. 2, 7). This organization confirms a transfer of deformed packages of sediment layer towards the east, supporting a triggering of the slump along the Apulian platform margin. However, the stacking of some $150 \mathrm{~m}$ of gravity-flow deposits above the third slump event in Tragjas (slumped unit 3) (Fig. 2) remains difficult to interpret. Among the various mechanisms invoked for slump triggering (Owen, 1987; Spalluto et al., 2007), two appear particularly relevant in the Ionian Basin. First "overloading", as supported by coarsening and thickening upward sequences (Fig. 2) that reflect an increase in sediment transfer from the platform during Uppermost Campanian to Maastrichtian. Secondly, "seismic shocks", supported by the regional extension of slumps, and the derived platform clasts observed in polygenic limeclast beds (FA1, Fig. 2). In Italy, Spalluto et al. (2007) reported three different earthquakes that affected Apulian platform deposits during Early Maastrichtian times. 
Colacicchi and Baldanza (1986) mentioned that slump intervals compose at least $50 \%$ of the sequence in the Upper part of the Cretaceous in the Scaglia Formation. Although the triggering nature of these slumps remains uncertain, the stacking of several deformed intervals in the Uppermost Campanian to Maastrichtian succession unequivocally testifies of major instabilities of the Apulian margin during this period. Also the Kruja platform was affected by tectonic instabilities, with strike-slip movements since the Late Santonian generating horst and graben structures. These instabilities are assumed to be responsible for the settling of $450 \mathrm{~m}$ of carbonate breccias in the Ionian Basin, and major unconformities in the platform domain (Heba and Prichonnet, 2009).

\section{Conclusions}

This study presents a detailed sedimentological analysis of seven outcrops exposing the Upper Cretaceous succession of the Ionian Basin (Albania) which is dominated by gravity-flow deposits. The time resolution was significantly improved by the combination of bio- and chronostratigraphical $\left({ }^{87} \mathrm{Sr} /{ }^{86} \mathrm{Sr}\right)$ methods, particularly with regard to date a major slump event (Latest Campanian-Early Maastrichtian) and the $\mathrm{K} / \mathrm{P}$ boundary. A sedimentological characterization of gravityflow deposits allow for the first time to work out the facies organization of the carbonate slope system in this region. The sedimentation to the west is strongly governed by the Apulian platform margin. However, both eastwards and westwards unidirectional current directions were recognized in the sediment record of the basinal successions, which could indicate the influence of both the Kruja and Apulia Platforms. This study also shows that preferential sediment sources exist in carbonate margin systems, without necessarily developing channelized morphologies. The studied successions expose a similar partitioning of four distinct intervals that can be described in terms of evolutionary stages of sedimentation. Tectonic instabilities of the shelf margin most likely played a significant role in the resedimentation of coarse ungraded deposits in the deep-basinal environment dominated by hemipelagites during Upper Albian to Cenomanian. The Turonian to Santonian period is characterized by deposition of autochtonous sedimentation, showing evidence of restricted external sediment input, possibly induced by a tectonic quiescence. The Upper Santonian documents a re-establishment of the gravity-flow system, likely triggered by tectonic activity, abruptly settling polygenic limeclast deposits related to inner apron settings, pointing out episodic dismantling of the Apulian platform. Coarsening and thickening upward sequences of calciclastic gravity-flows during the Campanian document a progradational trend basinward actively sustained by tectonic instabilities of the margin, and possibly increased by highstand shedding of the platforms. This dynamic of turbiditic resedimentation is abruptly cut off by the settling of syn-sedimentary deformed packages of coarse deposits, attesting major destabilizations in the region during the Maastrichtian. By means of paleogeographical reconstruction along the Apulian margin, this study provides valuable information regarding the dimensions of the carbonate slope system (thickness, and lateral extension) at a reservoir scale.

\section{Acknowledgements}

We thank Jean Borgomano and John Reijmer who gave wise and constructive review of the manuscript.

\section{References}

Aslop, G.I., Shmuel, M., 2011. Soft-sediment deformation within seismogenic slumps of the Dead Sea Basin. Journal of Structural Geology 33, 433-457.

Aubouin, J., 1959. Contribution a l'étude géologique de la Grèce septentrionale: les confins de l'Epire et de la Thessalie: place des Hellénides parmi les édifices structuraux de la Méditerranée orientale. Annales Géologiques des Pays Helléniques 10, (483 pp.).

Balcaen, L., Schrijver, I.D., Moens, L., Vanhaecke, L., 2005. Determination of the ${ }^{87} \mathrm{Sr} /{ }^{86} \mathrm{Sr}$ isotope ratio in USGS silicate reference materials by multi-collector ICP-mass spectrometry. International Journal of Mass Spectrometry 242, 251-255.
Bernet, K.H., Eberli, G.P., Gilli, A., 2000. Turbidite frequency and composition in the distal part of the Bahamas transect. In: Swart, P.K., Eberli, G.P., Malone, M.J., Sarg, J.F. (Eds.), Proc. ODP, Sci. Results 166, pp. 45-60.

Betzler, C., Reijmer, J.J.G., Bernet, K., Eberli, G.P., Anselmetti, F.S., 1999. Sedimentary patterns and geometries of the Bahamian outer carbonate ramp (Miocene-Lower Pliocene, Great Bahama Bank). Sedimentology 46, 1127-1143.

Borgomano, J.R.F., 1987. La plate-forme et le talus carbonatés du Cretacé Supérieur du Gargano et des Murges (Italie Méridionale)(Ph.D. thesis) University of Provence, Marseille (France) (626 pp.).

Borgomano, J.R.F., 2000. The Upper Cretaceous carbonates of the Gargano-Murge region, southern Italy: a model of platform-to-basin transition. AAPG Bulletin 10, 1561-1588.

Bosellini, A., Neri, C., Luciani, V., 1993. Platform margin collapses and sequence stratigraphic organization of carbonate slopes: Cretaceous-Eocene, Gargano promontory, southern Italy. Terra Nova 5, 282-297.

Bosellini, A., Morsilli, M., Neri, C., 1999. Long-term event stratigraphy of the Apulia platform margin (Upper Jurassic to Eocene, Gargano, southern Italy). Journal of Sedimentary Research 69, 1241-1252.

Bouma, A.H., 1962. Sedimentology of Some Flysch Deposits: A Graphic Approach to facies Interpretation. Elsevier, Amsterdam, pp. 217-222.

Brahimi, Q., Ikonomi J., Kanali J., Dodona E., Sadushi P., Pirdeni A., Bida Dh., 1987. Stratigraphy of Carbonate Deposits from Upper Triassic to Upper Eocene, Kurveleshi Belt. Gas and Petroleum Geological Institute of Fier, unpublished.

Brahimi, Q.. Kola, A., Sadushi, P., Ikonomi, J., Dodona, E., Kanali, J., Pirdeni, A. Myftari, A. 1992. Stratigraphy and Palaeogeography of Carbonate Deposits, Cika Tectonic Unit and Sazani Tectonic Zone. Gas and Petroleum Geological Institute of Fier, unpublished.

Carannante, G., Ruberti, D., Sirna, G., 1998. Senonian rudist limestones in the Sorrento Peninsula sequences (Southern Italy). Geobios 31, 47-68

Channell, J.E.T., d'Argenio, B., Horvath, F., 1979. Adria, the African promontory, in Mesozoic Mediterranean paleogeography. Earth-Science Reviews 15, 213-292.

Colacicchi, R., Baldanza, A., 1986. Carbonate turbidites in a Mesozoic pelagic basin: Scaglia formation, Apennines - comparison with siliciclastic depositional models. Sedimentary Geology 48, 81-105.

Cook, H.E., McDaniel, P.N., Mountjoy, E.W., Pray, L.C., 1972. Allochthonous carbonate debris flows at Devonian bank ("reef") margins. Bulletin of Canadian Petroleum Geology 20, 439-497.

Corbett, K.D., 1973. Open-cast slump sheets and their relationship to sandstone beds in a Upper Cambrian flysch sequence, Tasmania. Journal of Sedimentary Petrology 1, 147-159.

Crevello, P.D., Schlager, W., 1980. Carbonate debris sheets and turbidites, Exuma Sound, Bahamas. Journal of Sedimentary Petrology 50, 1121-1148.

D' Argenio, B., Horvath, F., Channel, J., 1980. Paleotectonic evolution of Adria, the African promontory. Géologie des chaînes Alpines issues de la Tethys. Memorize Bureau Recherche Géologie Minière 115, pp. 331-351.

Davis, C., Haughton, P., McCaffrey, W., Scott, E., Hogg, N., Kitching, D., 2009. Character and distribution of hybrid sediment gravity flow deposits from the outer Forties Fan, Paleocene Central North Sea, UKCS. Marine and Petroleum Geology 26, 1919-1939.

De Muynck, W., De Belie, N., Verstraete, W., 2009. Effectiveness of admixtures, surface treatments and antimicrobial compounds against biogenic sulfuric acid corrosion of concrete. Cement and Concrete Composites 31 (3), 163-170.

Dewever, B., Breesch, L., Mezini, A., Swennen, R., 2007. Sedimentological and marine eogenetic control on porosity distribution in Upper Cretaceous carbonate turbidites (central Albania). Sedimentology 54, 243-264.

Droxler, A.W., Schlager, W., 1985. Glacial versus interglacial sedimentation rates and turbidite frequency in the Bahamas. Geology 13, 799-802.

Drzewiecki, P.A., Simó, J.A., 2002. Depositional processes, triggering mechanisms and sediment composition of carbonate gravity flow deposits: examples from the Late Cretaceous of the south-central Pyrenees, Spain. Sedimentary Geology $146,155-189$.

Eberli, G.P., 1991. Calcareous turbidites and their relationship to sea-level fluctuations and tectonism. In: Einsele, G., Ricken, W., Seilacher, A. (Eds.), Cycles and Events in Stratigraphy. Springer-Verlag, Berlin, pp. 617-659.

Elliot, C.G., Williams, P.F., 1988. Sediment slump structures: a review of diagnostic criteria and application to an example from Newfoundland. Journal of Structural Geology 2 (10), 171-182.

Etienne, S., 2012. Caractérisation architecturale haute-résolution des lobes turbiditiques sableux confinés, exemple de la formation des grès d'Annot (Eocène-Oligocène, SE France). (PhD Thesis), Bordeaux I University, $315 \mathrm{pp}$.

Farell, S.G., 1988. Foliations developed during slump deformation of Miocene marine sediments. Cyprus, Journal of Structural Geology 6, 567-576.

Fisher, R.V., 1983. Flow transformations in sediment gravity flows. Geology 11, 273-274.

Graziano, R., 2000. The Aptian-Albian of the Apulia Carbonate Platform (Gargano Promontontory, southern Italy): evidence of palaeoceanographic and tectonic controls on the stratigraphic architecture of the platform margin. Cretaceous Research $21,107-126$

Graziano, R., 2001. The Cretaceous megabreccias of the Gargano Promontory (Apulia, southern Italy): their stratigraphic and genetic meaning in the evolutionary framework of the Apulia Carbonate Platform. Terra Nova 13, 110-116.

Hairabian, A., Borgomano, J., Masse, J.P., Nardon, S., 2014. 3-D stratigraphic architecture, sedimentary processes and controlling factors of cretaceous deep-water resedimented carbonates (Gargano Peninsula, SE Italy). Sedimentary Geology 317, 116-136 Special issue (in this volume).

Hampton, M.A., 1972. The role of subaqueous debris flow in generating turbidity currents. Journal of Sedimentary Petrology 42, 775-793.

Haughton, P., Davis, C., McCaffrey, W., Barker, S., 2009. Hybrid gravity flow deposits classification, origin and significance. Marine and Petroleum Geology 26, 1900-1918. 
Howarth, R.J., McArthur, J.M., 1997. Statistics for strontium isotope stratigraphy: a robust LOWESS fit to the marine strontium isotope curve for the period 0 to $206 \mathrm{Ma}$, with look-up table for the derivation of numerical age. Journal of Geology 105, 441-456.

Heba, G., Prichonnet, G., 2006. L'intervalle Crétacé terminal - Eocène de la marge passive d'Apulie en Albanie (massifs de Kruje-Dajt et de Makareshi, zone de Kruja): faciès organismes et cycles sédimentaires d'une plate-forme carbonate. Bulletin de la Societe Geologique de France 177 (5), 249-266.

Heba, G., Prichonnet, G., 2009. L'instabilité fini-Crétacé-Éocène de la marge passive d'Apulie en Albanie (plate-forme carbonatée de Kruja) et ses impacts sur la sédimentation. Bulletin de la Societe Geologique de France 180 (5), 431-448.

Karakitsios, V., 2013. Western Greece and Ionian Sea petroleum systems. AAPG Bulletin 97, 1567-1595.

Kneller, B., McCaffrey, W.D., 2003. The interpretation of vertical sequences in turbidite beds: the influence of longitudinal flow structure. Journal of Sedimentary Research 73, 706-713.

Landrein, P., Loreau, J.P., Fleury, J.J., 2001. Émersion généralisée intra- maastrichtienne de la plate-forme de Gavrovo-Tripolitza (Grèce); effets sur les populations de foraminifères Rhapydionininae. Bulletin de la Societe Geologique de France 172, 85-98.

Lowe, D.R., 1976. Grain flow and grain flow deposits. Journal of Sedimentary Petrology 46, 188-199.

Lowe, D.R., 1982. Sediment gravity flows: II. Depositional model with special reference to the deposits of high-density turbidity currents. Journal of Sedimentary Petrology 1 (52), 279-297.

McArthur, J.M., Thirlwall, M.F., Engkilde, M., Zinsmeister, W.J., Howarth, R.J., 1998. Strontium isotope profiles across $\mathrm{K} / \mathrm{T}$ boundary sequences in Denmark and Antarctica. Earth and Planetary Science Letters 160, 179-192.

McArthur, J.M., Howarth, R.J., Bailey, T.R., 2001. Strontium isotope stratigraphy: LOWESS version 3: best fit to the marine $\mathrm{Sr}$-isotope curve for 0-509 Ma and accompanying look-up table for deriving numerical age. The Journal of Geology 109, 155-170.

Meço, S., Aliaj, S., Turku, I., Bowen, R., 2000. Geology of Albania. Beiträge Zur Regionalen Geologie Der Erde. Gebr. Borntraeger.

Moisiu, L., Gurabardhi, L., 2004. Geological Map of South Albania, 1/200,000. Geological Research Institute, Petroleum and Gas Institute of Fier. Unpublished.

Mulder, T., Alexander, J., 2001. The physical character of subaqueous sedimentary density flows and their deposits. Sedimentology 48, 269-299.

Mulder, T., Cochonat, P., 1996. Classification of offshore mass movements. Journal of Sedimentary Research 1 (66), 43-57.

Mullins, H.T., Cook, H.E., 1986. Carbonate apron models: alternatives to the submarine fan model for paleoenvironmental analysis and hydrocarbon exploration. Sedimentary Geology 48, 37-79.

Owen, G., 1987. Deformation processes in unconsolidated sands. In: Jones, M.E., Preston, R.M.F. (Eds.), Deformation of Sediments and Sedimentary Rocks Geological Society Special Publications 29, pp. 11-24.

Playton, T.E., Janson, X., Kerans, C., 2010. Carbonate slopes. In: James, N.P., Dalrymple, R.W. (Eds.), Facies Models 4. Geological Association of Canada.

Read, J.F., 1982. Carbonate platforms of passive (extensional) continental margins: types, characteristics and evolution. Tectonophysics 81, 195-212.

Reijmer, JJ.G., Palmieri, P., Groen, R., 2012. Compositional variations in Calciturbidites and calcidebrites in response to sea-level fluctuations (Exuma Sound, Bahamas). Facies $58,493-507$.

Robertson, A.H.F., Shallo, M., 2000. Mesozoic-tertiary tectonic evolution of Albania in its regional Eastern Mediterranean context. Tectonophysics 316, 197-254.
Rubert, Y. Jati, M., Loisy, C., Cerepi, A., Foto, G., Muska, K., 2012. Sedimentology of resedimented carbonates: facies and geometrical characterisation of an upper cretaceous calciturbidite system in Albania. Sedimentary Geology 257-260, 63-77.

Schlager, W., Ginsburg, R.N., 1981. Bahama carbonate platforms - the deep and the past. Marine Geology 44, 1-24.

Schlager, W., Reijmer, J.J.G., Droxler, A.W., 1994. Highstand shedding of carbonate platforms. Journal of Sedimentary Research B64 (3), 270-281.

Simone, L., Carannante, G., Ruberti, D., Sirna, M., Sirna, G., Laviano, A., Tropeano, M., 2003. Development of rudist lithosomes in the Coniacian-Lower Campanian carbonate shelves of central-southern Italy: high-energy vs low-energy settings. Palaeogeography, Palaeoclimatology, Palaeoecology 200, 5-29.

Skourtsis-Coroneou, V., Solakius, N., Constantinidis, I., 1995. Cretaceous stratigraphy of the Ionian Zone, Hellenides, western Greece. Cretaceous Research 16, 539-558.

Spalluto, L., Caffau, M., 2010. Stratigraphy of the mid-Cretaceous shallow-water limestones of the Apulia Carbonate Platform (Murge, Apulia, southern Italy). Italian Journal of Geosciences 3, 335-352.

Spalluto, L., Moretti, M., Festa, V., Tropeano, M., 2007. Seismically-induced slumps in Lower-Maastrichtian peritidal carbonates of the Apulian Platform (southern Italy). Sedimentary Geology 196, 81-98.

Spence, G.H., Tucker, M.E., 1997. Genesis of limestone megabreccies and their significance in carbonate sequence stratigraphic models: a review. Sedimentary Geology 112, 163-193.

Steiger, R.H., Jager, E., 1977. Subcommission on geochronology: convention on the use of decay constants in geo- and cosmochronology. Earth and Planetary Science Letters 36 (3), 359-362.

Stow, D.A.V., Mayall, M., 2000. Deep-water sedimentary systems: new models for the 21st century. Marine and Petroleum Geology 17, 125-135.

Stow, D.A.V., Shanmugan, G., 1980. Sequence of structures in fine-grained turbidites: comparison of recent deep-sea and ancient flysch sediments. Sedimentary Geology $25,23-42$.

Swennen, R., Ferket, H., Benchilla, L., Roure, F., Ellam, R., SUBTRAP team, 2003. Fluid flow and diagenesis in carbonate dominated foreland fold and thrust belts: petrographic inferences from field studies of late-diagenetic fabrics from Albania, Belgium, Canada, Mexico and Pakistan. Journal of Geochemical Exploration 78-79, 481-485.

Talling, P.J., Masson, D.G., Sumner, E.J., Malgesini, G., 2012. Subaqueous sediment density flows: depositional processes and deposit types. Sedimentology 59, 1937-2003.

Thirlwall, M.F., 1991. Long-term reproducibility of multicollector Sr and Nd isotope ratio analysis. Chemical Geology: Isotope Geoscience Section 94, 85-104.

Vanhaecke, F., Vandecasteele, C., Vanhoe, H., Dams, R., 1992. Study of the intensity of M+, $\mathrm{M} 2+$ and $\mathrm{MO}+$ signals in ICP-MS as a function of instrumental parameters. Microchimica Acta 108, 335.

Vanhaecke, F., Gelaude, I., Moens, L., Dams, R., 1999. Solid sampling electrothermal vaporization inductively coupled plasma mass spectrometry for the direct determination of Hg in sludge samples. Analytica Chimica Acta 383, 253-261.

Vilasi, N., 2009. Etude d'analogues de reservoirs dans les chaînes plissées et leurs avant-pays : Sédimentologie, diagénèse, déformation et fracturation des systèmes carbonatés crétacés supérieurs - éocènes du Bassin Ionien (Albanie méridionale)(PhD Thesis) Ecole de mines de Paris, (216 pp.).

Walker, R.G., 1984. General introduction: facies, facies sequences and facies models, In: Walker, R.G. (Ed.), Facies Models, 2nd ed. Geosciences Canada 1, pp. 1-9.

Zapaterra, E., 1994. Source-Rock Distribution of the Periadriatic Region. 3 (78), 333-354. 